\title{
Chemosphere
}

\section{Chemical contamination alters the interactions between bacteria and phytoplankton --Manuscript Draft--}

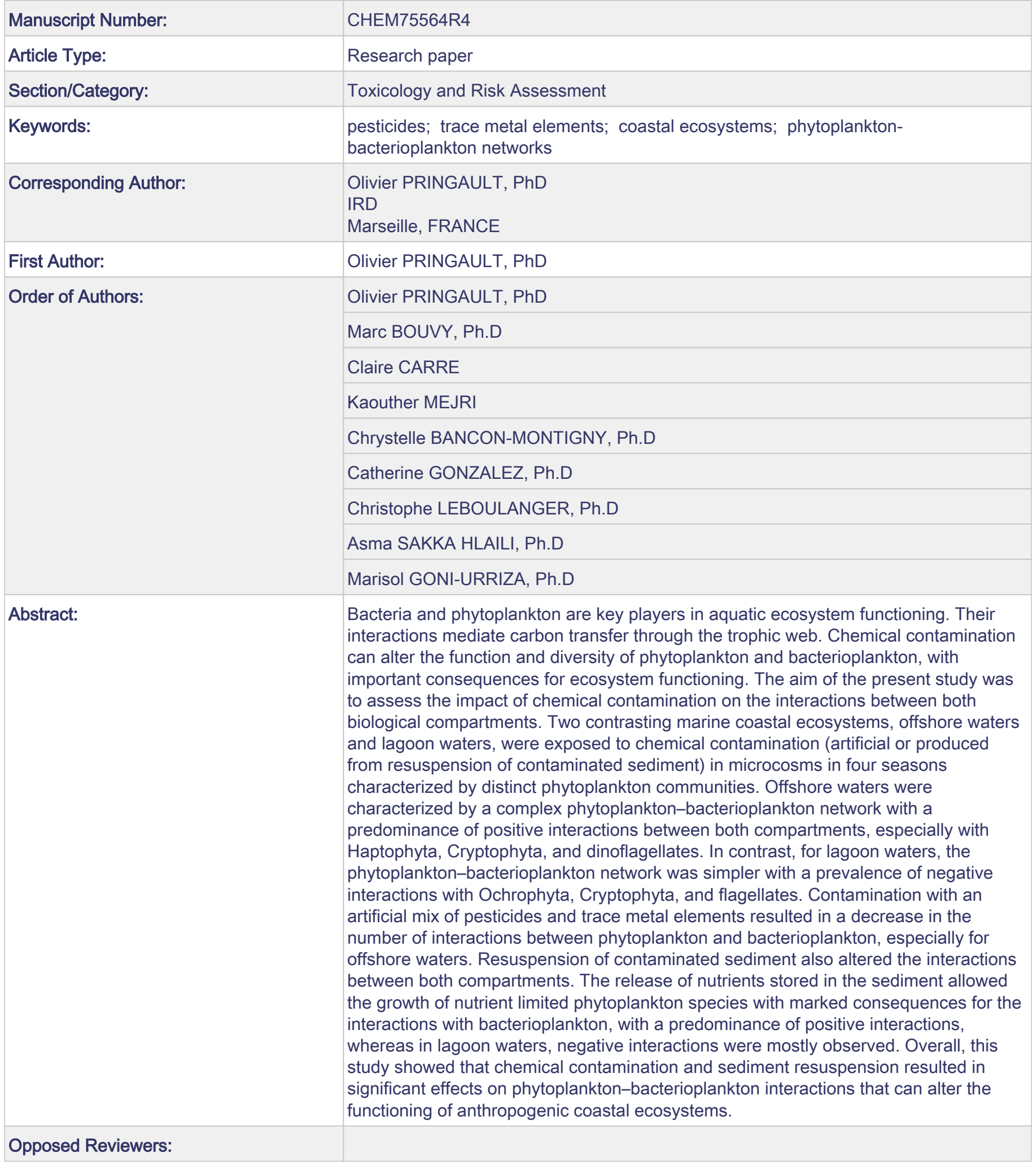




\section{Chemical contamination alters the interactions between bacteria and phytoplankton}

To be submitted to: CHEMOSPHERE

Olivier PRINGAULT ${ }^{* 1,2,3}$, Marc BOUVY², Claire CARRE², Kaouther MEJRI ${ }^{3}$, Chrystelle BANCON-MONTIGNY ${ }^{4}$, Catherine GONZALEZ ${ }^{5}$, Christophe LEBOULANGER ${ }^{2}$, Asma SAKKA HLAILI ${ }^{3,6}$, Marisol GONI-URRIZA ${ }^{7}$

${ }^{1}$ Aix Marseille Université, Université de Toulon, CNRS, IRD, MIO UM 110, 13288, Marseille, France.

${ }^{2}$ MARBEC Univ Montpellier, IRD, Ifremer, Montpellier, France.

${ }^{3}$ Faculté des Sciences de Bizerte, Université de Carthage, 7021 Zarzouna, Bizerte, Tunisie.

${ }^{4}$ UMR 5569 HydroSciences HSM Univ Montpellier, CNRS, IRD CC57 34090 Montpellier cedex 5 .

${ }^{5}$ IMT Mines Alès, 6 avenue de Clavières, 30319 Alès cedex, France.

${ }^{6}$ Laboratoir d'Ecologie, de Biologie et de Physiologie des organismes aquatiques, LR18ES41, Université de Tunis El Manar, Tunis, Tunisie.

'Universite de Pau et des Pays de l'Adour, E2S UPPA, CNRS, IPREM, 64000, Pau, France.

${ }^{*}$ Corresponding author 


\section{Highlights}

- Phytoplankton-bacterioplankton interactions were studied in lagoon and offshore waters

- The two ecosystems exhibited specific phytoplankton-bacterioplankton networks

- A more complex network was observed in offshore waters

- Positive interactions between phytoplankton and bacterioplankton dominated in offshore waters

- Contamination resulted in a simplification of the phytoplankton-bacterioplankton network 


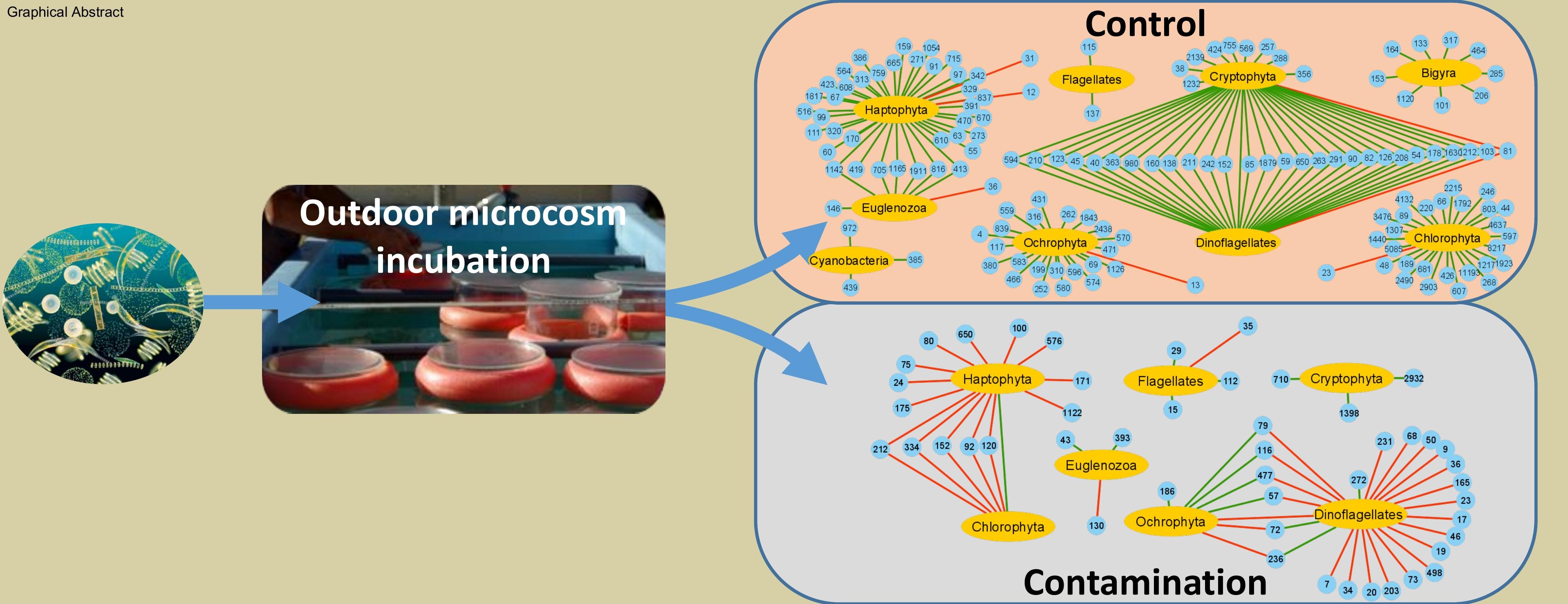




\section{Abstract}

2 Bacteria and phytoplankton are key players in aquatic ecosystem functioning. Their

3 interactions mediate carbon transfer through the trophic web. Chemical contamination

4 can alter the function and diversity of phytoplankton and bacterioplankton, with

5 important consequences for ecosystem functioning. The aim of the present study was

6 to assess the impact of chemical contamination on the interactions between both

7 biological compartments. Two contrasting marine coastal ecosystems, offshore waters and lagoon waters, were exposed to chemical contamination (artificial or produced

9 from resuspension of contaminated sediment) in microcosms in four seasons characterized by distinct phytoplankton communities. Offshore waters were characterized by a complex phytoplankton-bacterioplankton network with a predominance of positive interactions between both compartments, especially with Haptophyta, Cryptophyta, and dinoflagellates. In contrast, for lagoon waters, the phytoplankton-bacterioplankton network was simpler with a prevalence of negative interactions with Ochrophyta, Cryptophyta, and flagellates. Contamination with an artificial mix of pesticides and trace metal elements resulted in a decrease in the number of interactions between phytoplankton and bacterioplankton, especially for offshore waters. Resuspension of contaminated sediment also altered the interactions between both compartments. The release of nutrients stored in the sediment allowed the growth of nutrient limited phytoplankton species with marked consequences for the interactions with bacterioplankton, with a predominance of positive interactions, whereas in lagoon waters, negative interactions were mostly observed. Overall, this study showed that chemical contamination and sediment resuspension resulted in significant effects on phytoplankton-bacterioplankton interactions that can alter the functioning of anthropogenic coastal ecosystems.

Keywords

Pesticides, trace metal elements, coastal ecosystems, phytoplankton-bacterioplankton networks 
31 In aquatic pelagic systems, phytoplankton and bacteria represent the most important producers of particulate organic material from inorganic and dissolved organic sources (Berglund et al., 2007). The organic matter can be transferred to higher trophic levels through different food webs, ranging from the microbial loop to the classic herbivore pathways depending on resource availability and prey size (Azam et al., 1983; Berglund et al., 2007). As a general rule in marine coastal and estuarine ecosystems, bacteria mediate more carbon than is produced in situ, resulting in net heterotrophy of the system (Morán et al., 2013). The ecosystem is thus depending on the availability of other sources of carbon such as recycled autochthonous carbon sources (Fouilland et al., 2014) or allochthonous terrestrial sources (Fouilland et al., 2018a; Morán et al., 2002). Since bacterioplankton and phytoplankton represent the first levels of pelagic marine food webs, any perturbation (natural or anthropogenic) impacting these key players is likely to impact the higher trophic levels and the ecosystem functioning depending on the strength and nature of the biological interactions within the aquatic trophic web (Sakka Hlaili et al., 2014). Phytoplankton-bacterioplankton interactions have received increasing attention in recent decades. These interactions comprise four major modes as clearly described by Grossart and Simon (2007) and Amin et al. (2012): (1) a symbiotic association between can inhibit bacterial growth by releasing antibiotic compounds, while bacteria can also act as parasites on phytoplankton leading to cell lysis and death of their hosts, (3) a commensal association with no positive or negative effect between both compartment; and (4) phytoplankton is only loosely associated with bacteria, thus allowing competition for limiting nutrients. The ecological relationships between 
association in aquatic environments (Seymour et al., 2017). Phytoplanktonbacterioplankton interactions strongly influence carbon and nutrient cycles, regulate the productivity and stability of aquatic food webs (Seymour et al., 2017), and affect ocean-atmosphere fluxes of climatically relevant chemicals such as $\mathrm{CO}_{2}$ (Cole, 1982) or dimethyl sulfide (DMS) (Yoch, 2002). The shared evolutionary history of these organisms (Cirri and Pohnert, 2019) has played an important role in shaping global biogeochemistry and aquatic ecosystem functioning (Seymour et al., 2017).

Anthropogenic perturbations like global warming (Hoppe et al., 2008), acidification (Hornick et al., 2017) or nutrient loading (Prieto et al., 2015) can alter the interactions between phytoplankton and bacterioplankton. For example, a nutrient increase can modify the metabolism of phytoplankton-associated bacteria and consequently the physiology of phytoplankton (Russo et al., 2016). Recent studies have shown that toxic contaminants such as herbicides can indirectly affect bacterial communities through their tight coupling with herbicide-sensitive phytoplankton (Goni-Urriza et al., 2018).

Natural or artificial exposure to contaminants can also promote increased tolerance to toxic compounds within phytoplankton and bacterioplankton communities (Blanck, 2002). In addition, recent works have demonstrated that bacteria can increase toxic tolerance of their associated phytoplankton species in culture (Fouilland et al., 2018; Levy et al., 2009). Sensitivity of phytoplankton to contaminants is also influenced by the seasons, since seasonal environmental conditions can increase or decrease the success of tolerant species (Berard et al., 1999; Gregorio et al., 2012). Although the phytoplankton-bacteria relationships through metabolite exchanges are well studied, little is known regarding the impact of chemical contaminants on the interactions between phytoplankton and associated bacteria.

The aim of the present study was to assess the consequences of chemical contamination on the interactions between bacterioplankton and phytoplankton in two contrasting ecosystems characterized by distinct phytoplankton species according to season. For that purpose, microcosm incubations were performed during different seasons with offshore and lagoon waters exposed to a sediment elutriate or an artificial mixture of 
contaminants mimicking the main contaminants present in sediment elutriate (pesticides and trace metal elements (TME)). Previous works have shown that chemical contamination and sediment resuspension impacted the coastal marine chemical environment differently (Bancon-Montigny et al., 2019) depending on the water masses (open or semi enclosed) with important consequences for ecosystem functioning (Pringault et al., 2020, 2016). The present study is based on the same sampling and experimental approach extensively described in Bancon-Montigny et al. (2019) and Pringault et al. (2020), dealing respectively with contaminant dynamics in water and plankton, and with biogeochemical coupling between bacteria and phytoplankton. Here we focus on the consequences of contamination for phytoplankton and bacterioplankton diversity, and aim to decipher the phytoplankton-bacterioplankton interactions and the resulting microbial networks.

\section{Materials and Methods}

\subsection{Study sites and sampling}

This study was performed in Southwestern Mediterranean ecosystems, the bay and the lagoon of Bizerte (Fig. S1, Supplementary materials), during four seasons, spring (April 2014), winter (February 2015), fall (November 2015), and summer (July 2016).

Like most of the Mediterranean coastal lagoons, the Bizerte lagoon (lagoon station, L), to the North of Tunisia, is a polluted coastal ecosystem subject to intense industrialization, urbanization, and agriculture pressures, as well as pressures from commercial and naval shipping harbors (Pringault et al., 2020). Consequently, sediments are strongly contaminated by a wide range of pollutants, including metals and organic compounds (polycyclic aromatic hydrocarbons (PAHs) and pesticides) (Barhoumi et al., 2014a, 2014b; Triki et al., 2017). The Bizerte bay (offshore station, O) is less contaminated than the lagoon (Pringault et al., 2020), although polar pesticides including herbicides have been detected in the lagoon watershed (Mhadhbi et al., 2019) and local PAH contamination has been recorded in the effluent from an oil refinery located on the shore of the bay (Zrafi-Nouira et al., 2009, 2008). Water sampling was 
carried out from $2 \mathrm{~m}$ depth in a lagoon station (station L, $37^{\circ} 12^{\prime} 43.96^{\prime \prime \prime} \mathrm{N}, 9^{\circ} 50^{\prime} 79.78^{\prime \prime}$
E) and an offshore station (station
$\mathrm{O}, 37^{\circ} 16^{\prime} 46.46^{\prime \prime} \mathrm{N}, 9^{\circ} 53^{\prime} 50.98^{\prime \prime}$
E) (Fig. S1,

117 Supplementary materials) following the sampling procedure described in Pringault et al. (2016). Water samples were collected from $2 \mathrm{~m}$ depth, corresponding to the chlorophyll a maximum along the water column (Sakka Hlaili et al., 2007). Upon sampling, water was filtered through $200 \mu \mathrm{m}$ mesh to remove larger particles and the metazooplankton thus minimizing grazing effects during incubation.

122 Sediment elutriate was obtained from polluted sediment resuspension following the protocol described by Bonnet et al. (2000) and recommended by the Environmental Protection Agency (US EPA). Briefly, polluted sediment was sampled using a Van Veen grab at $4 \mathrm{~m}$ depth in front of a cement factory in the lagoon channel (station $\mathrm{CH}$, $37^{\circ} 15^{\prime} 40.22^{\prime \prime} \mathrm{N}, 9^{\circ} 51^{\prime} 30.49^{\prime \prime}$ E Fig. S1), one of the most polluted sites in the Bizerte lagoon (Ben Said et al., 2010; Pringault et al., 2020; Triki et al., 2017). Overlying channel water was also sampled at the same time following the sampling procedure used for the offshore and lagoon waters. Just after sampling, the sediment was sieved (2 mm mesh) to remove large particles and stored in a cool box until its return to the laboratory. In the laboratory, sediment was mixed with channel water (1:4 w/v ratio), and sediment was gently stirred for $8 \mathrm{~h}$. After a $12 \mathrm{~h}$ settling period, the overlying solution, thereafter called "elutriate", was smoothly siphoned out and stored in the dark at $4{ }^{\circ} \mathrm{C}$ until spiking in microcosms few days later (Pringault et al., 2016). The same protocol for sediment elutriate preparation was applied for the four studied seasons. This protocol has been successfully used to characterize the contamination

137 level and toxicity of sediments using non-adapted species (Bonnet et al., 2000; Carr 138 and Chapman, 1995).

\subsection{Incubation procedure}

140 During the four studied seasons, seawater was incubated for four days in 9 L glass 141 microcosms (22.5 cm diameter and $23 \mathrm{~cm}$ height). The microcosms were covered with 142 a quartz lid to allow full penetration of natural sunlight, including UV radiation, 
143 according to the protocol described in Pringault et al $(2020,2016)$ and briefly detailed

144 below. A series of triplicate microcosms was filled with $1.5 \mathrm{~L}$ of elutriate and 145 completed with $4.5 \mathrm{~L}$ of sample water ( $\mathrm{L}$ and $\mathrm{O}$ stations) to achieve a final dilution of $14625 \%$ (contaminated water microcosms (CW). Another series of triplicate microcosms 147 (artificial contaminated water microcosms (ACW)) was filled with $6 \mathrm{~L}(\mathrm{O}$ and $\mathrm{L}$ 148 stations) and spiked with an artificial solution of TME ( $\mathrm{Ni}, \mathrm{Cu}, \mathrm{Zn}, \mathrm{Cd}, \mathrm{As}, \mathrm{Pb})$, and 149 pesticides and some metabolites (acetochlore, alachlore, DCPU 1-(3,4150 dichlorophenyl)urea, DIA deisopropylatrazine, diuron, linuron, and simazine). The 151 final concentrations of metals and pesticides were adjusted to mimic the 152 concentrations observed in elutriate (Table S1, Supplementary materials) (see Bancon153 Montigny et al., 2019 for more details). This treatment was used to assess the impact 154 of the main chemical compounds observed in the elutriate without the possible 155 confounding effects of enhanced nutrients, DOC or benthic microorganisms that are 156 released during sediment resuspension and present in the elutriate in the CW 157 treatment. Lastly, a third series of triplicate microcosms (Control, C) was filled with 6 158 L of sample water (O and L stations). All microcosms were incubated during 96h 159 outdoors under natural sunlight in a $3 \mathrm{~m}^{3}$ pool with circulating seawater (open system)

160 to maintain in situ water temperature. Two light sensors (Skye, England), measuring 161 incident ultraviolet A and B radiation (315-380 nm, SKU 420 and 280-315 nm, SKU 162430 , respectively) and photosynthetically active radiation (PAR; 400-700 nm, quantum 163 SKP 215) were installed to monitor the light received at the surface of the microcosms.

\section{$164 \quad 2.3$ Chemical analyses}

165 Chemical analyses of dissolved organic carbon (DOC), Chlorophyll a (Chla); the 166 nutrients $\left(\mathrm{SiOH}_{4}, \mathrm{NH}_{4}, \mathrm{NO}_{3}, \mathrm{NO}_{2}\right.$ ), and TME and organic contaminants (pesticides and 167 PAHs) were performed using the analytical protocols described in Bancon-Montigny 168 et al. (2019) and Pringault et al. (2016). 
170 Water samples $(245 \mathrm{~mL})$ immediately fixed with buffered formaldehyde at $2 \%$ final 171 concentration were collected at the two stations $\mathrm{O}$ and $\mathrm{L}$, and at the end of the $96 \mathrm{~h}$ 172 incubations in each microcosm. Species identification and counts were performed with 173 a BX 60 Olympus microscope equipped with a Progress C3-cooled Janoptik camera 174 following the procedure of Pringault et al (2020). Each species was determined to the 175 lowest taxonomic level according to Tomas et al. (1997), Hoppenrath et al. (2009), 176 Kraberg et al. (2010), Viličić (2014), and the WoRMS database 177 (http://www.marinespecies.org). Counts were performed according to the Utermöhl's 178 concentration technique (Utermöhl, 1958) under an inverted microscope (Olympus

179 IX70). Each taxon was counted individually, except for Cyanophyceae spp, Chaetoceros 180 spp, Pseudo-nitzchia spp, Prymnesiophyceae spp and Euglenoides spp which were 181 grouped into global taxa due to the difficulties of species identification. Two groups of 182 flagellates were distinguished by size class $(<10 \mu \mathrm{m}$ and $>10-15 \mu \mathrm{m})$.

183

184

185

186

187

188

189

190

191

192

193

194 195 196

\subsection{Bacterioplankton diversity}

Bacterioplankton was sampled at the two stations $\mathrm{O}$ and $\mathrm{L}$, and at the end of the $96 \mathrm{~h}$ incubations in each microcosm. Samples were processed as previously described (Goni-Urriza et al., 2018). Briefly, after water filtration (1000 ml) using sterile filters (0.2 $\mu \mathrm{m}$ porosity), filters were immediately frozen in liquid nitrogen and stored at -80 until DNA and RNA co-extraction. Nucleic acid extraction was performed coupling the Fast RNA ProSoil direct kit (MpBIO) with the AllprepDNA/RNA mini kit (QIAGEN). DNA contamination in RNA samples was eliminated with the RNase-Free DNase Set (QIAGEN). The RNA reverse transcription was performed using the M-MLV RT enzyme (Invitrogen) with 20-50 ng of RNA, RNase OUT (Invitrogen) and 50ng of random primers, according to the manufacturer's instructions.

94 The composition of the bacterial community was assessed targeting the V3-V4 region 95 of the 16S rRNA gene as described elsewhere (Goni-Urriza et al., 2018). Briefly, PCR amplifications of extracted DNA and synthetized cDNA were performed with the 
197 AmpliTaq Gold 360 Master mix (Applied Biosystems) and 343F-784R primers' set

198 following the procedure described in Goni-Urriza et al. (2018). PCR amplicons were 199 sequenced using the MiSeq 250-paired technology (Illumina). Raw sequences are 200 available on the NCBI SRA database (National Center for Biotechnology Information 201 Sequence Read Archive) under the accession number PRJNA391504.

202 QIIME pipeline was used to analyze raw sequences. Briefly, sequences with a quality 203 score <20 were discarded before to remove chimeras (UCHIME, denovo). 204 USEARCH61 was used to generate OTUs and UCLUST with Silva database (v. 119) to 205 determine the affiliation of the OTUs' representative sequences. Prior to data 206 normalization (rarefyseq.py), reads affiliated with chloroplasts and singletons were 207 removed.

\subsection{Statistical analysis}

209 Phytoplankton and bacterioplankton species richness $(S)$ was determined by the 210 number of taxa (phytoplankton) and OTUs (bacterioplankton). The Shannon diversity $211(H)$ index was estimated using the following equation (Hill et al., 2003):

$$
H=\sum_{i=1}^{S} P_{i} \log P_{i}
$$

213 where $P i$ represents the relative abundance of species or OTU $i$ in each sample and $S$ 214 the species richness. Analysis of variance (ANOVA) was performed to test the 215 significance of the differences observed between treatments, stations and seasons. 216 Prior to ANOVA, homogeneity of variance (Levene's test) and normality (Shapiro217 Wilk test) were determined. When these conditions were not met, differences between 218 treatments were tested using the non-parametric Kruskal-Wallis ANOVA test. A 219 posteriori paired multiple-comparisons were then performed using Tukey's HSD test. 220 All statistical tests were carried out with the level of significance set at $\mathrm{p}<0.05$. For 221 multivariate analysis of the phytoplankton and bacterioplankton diversity, the 222 triplicate data were averaged and the relative abundance was transformed with arcsin $223\left(\mathrm{x}^{\wedge} 0.5\right)$ to obtain a normal data distribution (Legendre and Legendre, 1998) according 
224 to the procedure described in Pringault et al (2016). Three canonical correspondence 225 analyses (CCA) were performed, following the recommendations Ramette (2007) 226 using the MVSP v3.12d software (Kovach Computing Service, Anglesey Wales). The 227 first two CCAs used either the 100 most abundant OTUs or the phytoplankton groups 228 as response variables and concentrations of chemicals, TMEs, nutrients and DOC as 229 explanatory variables. The explanatory variables with variance inflation factors (VIF) $230>20$ were removed to eliminate collinearity of environmental variables. For 231 bacterioplankton diversity, only OTUs with at least ten reads were considered in order 232 to reduce the effects of rare OTUs (Goni-Urriza et al., 2018). Since similar 233 environmental variables were identified as structuring factors for bacterioplankton 234 and phytoplankton communities, a third CCA was performed with the 100 most 235 abundant bacterioplankton OTUs as response variables and the phytoplankton groups 236 as explanatory variables, in order to determine whether phytoplankton were 237 structuring the bacterioplankton communities. Spearman correlation was calculated 238 with XLSTAT software (Addinsoft, Bordeaux France) between the phytoplankton 239 groups and the 100 most abundant OTUs. Significant $(\mathrm{p}<0.05)$ Spearman correlation 240 values $>|0.8|$ were then used to design phytoplankton-bacterioplankton networks 241 with the help of the CYTOSCAPE software. Phytoplankton species and bacterial OTU 242 are represented as nodes, and node-node interactions (edges) represented as links 243 (Shannon et al., 2003).

\subsection{In situ bacterioplankton and phytoplankton diversity}

246 The two stations were characterized by distinct environmental conditions with clear 247 seasonal effects for $\mathrm{T}^{\circ} \mathrm{C}$ and Chla. Chla concentrations did not exceed $1 \mu \mathrm{g} \mathrm{L}^{-1}$ in 248 offshore waters, with a minimum observed in winter and a maximum during spring. 249 On the contrary, maximum Chla was observed during fall in lagoon waters with a 250 value close to $5 \mu \mathrm{g} \mathrm{L}{ }^{-1}$. Dissolved organic carbon was significantly $(\mathrm{p}<0.05)$ higher in 251 lagoon waters, with concentrations up to $2.5 \mathrm{mg} \mathrm{C} \mathrm{L}^{-1}$ in winter, whereas in offshore 
waters, DOC was around $1 \mathrm{mg} \mathrm{C} \mathrm{L}^{-1}$. Similarly, nutrient concentrations were higher in lagoon waters (Table S1, Supplementary materials). Pesticides were most abundant in Lagoon waters especially DIA or Simazine, as well as some TME, Ni, Zn or Mn (Table S1, Supplementary materials).

These distinct environmental conditions were concomitant to specific phytoplankton communities in offshore and lagoon waters with clear seasonal effects for both ecosystems (Fig. 1 upper panel). In spring and fall, dinoflagellates, with high abundances of Gonyaulax sp., Heterocapsa sp., and Prorocentrum sp. were the dominant phytoplankton group in lagoon waters representing up to 55\% relative abundance (spring), while in offshore waters flagellates and dinoflagellates (mostly Scrippsiella sp.) accounted together for more than $70 \%$ of the relative abundance in both seasons. Summer was characterized by a strong dominance of Ochrophyta (93\%) in the lagoon with a dense population of Chaetoceros sp. (68\% of relative abundance), and to lesser extent in offshore waters (56\%). During winter, Haptophyta (Coccolithophorids sp.) were the dominant (42\%) phytoplankton taxa in offshore waters, while in the lagoon, flagellates (38\%) and Ochrophyta (27\%) accounted for up to $65 \%$ of the relative abundance. Diversity indices (Shannon index and species richness) exhibited distinct seasonal patterns with significant $\left(\mathrm{F}_{3,20}=58.25, \mathrm{p}<0.05, \mathrm{~F}_{3,20}=3.42 \mathrm{p}<0.05\right.$, for Shannon index and species richness, respectively) differences between lagoon and offshore waters (Fig. S2, Supplementary materials). Species richness (S) and Shannon index (H) were significantly higher $\left(\mathrm{F}_{1,22}=26.82 \mathrm{p}<0.05, \mathrm{~F}_{1,22}=8.07 \mathrm{p}<0.05\right.$, for Shannon index and species richness, respectively) in offshore waters with maximum values observed for fall $(\mathrm{H}=2.91 \pm 0.07, \mathrm{~S}=27.7 \pm 5.5)$, whereas the lowest values for the Shannon diversity 275 index were observed during summer in both ecosystems.

276 A total of 203562 distinct OTUs were identified from the 16S rDNA library in the 277 whole dataset (in situ and microcosm incubation). As observed for phytoplankton, in 278 situ bacterioplankton diversity also showed variations according to season and 279 ecosystem (Fig. 1 lower panel). Gammaproteobacteria (dominated by Alteromonas sp., Marinobacterium sp., Litoricola sp., and SAR86 clade) represented the most dominant 
groups irrespective of the season for both offshore and lagoon waters, with up to $42 \%$ 282 of the relative abundance in offshore waters during winter. Flavobacteria (21-34\%) and Alphaproteobacteria (12-26\%) were the other dominant groups with a relative abundance greater than 10\%. Regarding the less dominant groups, Cytophagia (1.6$4.9 \%)$ and Betaproteobacteria (2.2-3.8\%) abundances were greater in lagoon waters, whereas Deltaproteobacteria (1.4-5.0\%) and Deferribacter sp. (0.6-3.7\%) abundances were higher in offshore waters. Diversity indices (Shannon index) exhibited distinct significant $\left(\mathrm{F}_{3,20}=6.51, \mathrm{p}<0.05\right)$ seasonal patterns (Fig. S2) in lagoon and offshore waters, with minimum values during spring $(4.30 \pm 0.28$ and $4.03 \pm 0.05$ for lagoon and offshore waters, respectively) and winter (4.20 \pm 0.06 and $4.47 \pm 0.04$ for lagoon and offshore waters, respectively). Maximum values were observed during summer (6.75 \pm 0.08 and $6.74 \pm 0.12$ for lagoon and offshore waters, respectively) and fall (6.74 \pm 0.16 and $6.94 \pm 0.12$ for lagoon and offshore waters, respectively). No significant $(\mathrm{p}>0.05)$ differences were observed for the Shannon index and species richness between lagoon and offshore waters.

\subsection{Impact of contamination on bacterioplankton and phytoplankton communities}

The impact of chemical contamination on the phytoplankton community was ecosystem and season dependent. As a general rule, the most pronounced effects on the relative abundance of the phytoplankton groups (compared to the control treatment) were observed with elutriate exposure especially during fall, whereas artificial contamination by a pesticide and TME mixture provoked minor changes in phytoplankton community structure (Fig. 2, upper panel). The changes in relative abundances were generally more marked in offshore waters relative to lagoon waters, especially in fall where flagellates (60\% relative abundance) became the dominant group in the CW microcosm while they represented less than $10 \%$ of in situ relative abundance. When all seasons were taken into account, exposure to elutriate provoked a slight but significant $\left(\mathrm{F}_{2,33}=13.41, \mathrm{p}<0.05\right)$ increase in species richness in lagoon waters, whereas no significant effect was observed for the Shannon diversity index. In contrast, in offshore waters, both treatments (ACW and CW) resulted in a significant 
$310\left(\mathrm{~F}_{2,33}=16.58, \mathrm{p}<0.05\right)$ reduction of the Shannon index (Fig. S3) and the specific richness $311\left(\mathrm{~F}_{2,33}=7.83, \mathrm{p}<0.05\right)(\mathrm{Fig} . \mathrm{S} 4)$. CCA performed with the phytoplankton groups as 312 response variables, and the contaminants and nutrients as explanatory variables (Fig. 313 S5), showed that the impact of contaminants on phytoplankton structure was less 314 marked than that imposed by spatial and temporal effects. Seasons were discriminated 315 along axis 1, whereas stations were separated along axis 2. Nitrate, ammonium, 316 silicate, $\mathrm{DOC}, \mathrm{Ni}$, and $\mathrm{Zn}$ were identified as positive structuring factors for the 317 phytoplankton community in the lagoon ecosystem, especially during winter and 318 spring. In contrast, offshore phytoplankton communities were negatively impacted by $\mathrm{Zn}, \mathrm{Ni}$, pesticides, and $\mathrm{Cu}$, especially during spring and summer (Fig. S5). Among the different phytoplankton groups, dinoflagellates and Haptophyta exhibited the lowest abundance in ACW and CW treatments relative to the control (Fig. S6), whereas Ochrophyta and Cryptophyta abundances were similar in ACW relative to the control value, with an even higher abundance in CW for Cryptophyta (Fig. S6).

For the bacterioplankton community, the impacts of contamination followed the same patterns as those observed for phytoplankton, with a more marked effect for the sediment elutriate relative to the artificial mixture contamination (Fig. 2, lower panel). The relative abundance of Gammaproteobacteria significantly increased $\left(F_{2,33}=21.40\right.$, $\mathrm{p}<0.05, \mathrm{~F}_{2,33}=56.63, \mathrm{p}<0.05$, for offshore waters and lagoon waters, respectively) in the CW treatment especially in fall and winter, irrespective of the ecosystem, while relative abundance of Alphaproteobacteria $\left(\mathrm{F}_{2,33}=14.07, \mathrm{p}<0.05\right.$ for offshore waters $)$ and Flavobacteria $\left(F_{2,33}=23.24, p<0.05, F_{2,33}=78.28, p<0.05\right.$, for offshore waters and lagoon waters, respectively) significantly decreased. Nevertheless, no significant changes were observed for the diversity indices (Figures S3 and S4, Supplementary materials). As observed for the phytoplankton community, the consequences of contamination were more evident in the offshore station although changes were partially masked by the seasonal and spatial effects as indicated by the canonical correspondence performed with the 100 most abundant OTUs as response variables, and the contaminants and nutrients as explanatory variables (Fig. S5, Supplementary 
materials). Interestingly, the structuring environmental chemical factors identified for

340 the bacterioplankton community were roughly similar to those observed for the 341 phytoplankton community. Lagoon communities were structured by nitrate, DOC, Ni, $342 \mathrm{Zn}, \mathrm{Cd}$, and $\mathrm{Cu}$, especially during spring and winter, whereas they negatively 343 impacted the offshore community in summer and fall.

\subsection{Impact of contamination on bacterioplankton-phytoplankton interactions}

345 Since similar environmental variables were identified as structuring factors for 346 bacterioplankton and phytoplankton communities, CCA was performed with the 100 347 most abundant OTUs as response variables and the phytoplankton groups as 348 explanatory variables (Fig. 3). The two first axes explained almost $30 \%$ of the variance 349 observed. Seasons were separated along axis 1 and ecosystem along axis 2 . The impact 350 of phytoplankton groups on the bacterioplankton community was clearly season and ecosystem dependent. Winter bacterial communities were mostly explained by flagellates especially for offshore waters and, by Haptophyta and Euglenozoa for lagoon waters. In both ecosystems, summer communities were structured by Ochrophyta, whereas dinoflagellates were identified as a structuring factor during fall. In order to estimate the possible interactions between bacterioplankton and phytoplankton, Spearman correlation coefficients were calculated between the relative abundance of the 100 most abundant bacterioplankton OTUs and the phytoplankton groups observed at the end of the microcosm treatments for both ecosystems (Fig. 4). Spearman correlation coefficients were also calculated within the 100 most abundant

360 bacterial OTUs, in order to assess interactions among the bacterioplankton (Fig. S7, 361 Supplementary materials). Highly significant Spearman correlations $(>0.8)$ were then used to draw bacterioplankton-phytoplankton networks as a function of the

363 microcosm treatment for lagoon (Fig. 5) and offshore waters (Fig. 6). The nature 364 (positive or negative) and the number of significant interactions $(\mathrm{p}<0.05)$ were strongly dependent on the ecosystem and the microcosm treatments (Fig. 4). In the 366 control treatment, positive interactions dominated, especially in offshore waters (451 367 positive vs. 113 negative) and to a lesser extent in lagoon waters (384 positive vs. 227 
negative). Differences were also observed depending on the phytoplankton groups:

369 Cyanobacteria, Bigyra, and Haptophyta showed mostly positive interactions with 370 bacterioplankton, whereas a predominance of negative interactions was observed for 371 flagellates and Ochrophyta, especially in lagoon waters. Contamination effects on the 372 bacterioplankton-phytoplankton networks depended on the impacted ecosystem. In 373 offshore waters, contamination resulted in an increase of negative interactions 374 concomitant with a reduction of positive interactions., irrespective of the microcosm 375 treatment (Fig. 6 and Fig. 4 lower panel). Interestingly, negative interactions became 376 dominant for dinoflagellates, Chlorophyta, and Haptophyta in the CW treatment, 377 whereas these groups exhibited a predominance of positive interactions with bacteria 378 in control conditions (Fig. 6). In contrast, for lagoon waters, no marked changes for 379 positive and negative interactions were observed between control and CW treatments 380 (Fig. 4), whereas exposure to artificial contamination resulted in a similar decrease for 381 both positive and negative interactions (Fig. 5 and Fig. 4 upper panel). Among the 382 Gammaproteobacteria, the dominant bacterial genus, Marinobacterium sp. exhibited 383 positive interactions with several phytoplankton taxa, irrespective of the treatments, 384 whereas Litoricola sp. appeared less associated with phytoplankton (Table S2, 385 Supplementary materials). Interactions among the most abundant OTUs were largely 386 dominated by positive interactions (Fig. S7, Supplementary materials) irrespective of 387 the treatments and the sampling site. Interestingly, for both ecosystems, chemical 388 contamination and sediment elutriate resulted in an increase of interactions between 389 OTUs; the large proportion of positive interactions (79-85\%) observed in control 390 microcosms remained similar in ACW and CW treatments.

392 The aim of the present study was to assess the consequences of chemical contamination 393 on bacterioplankton-phytoplankton interactions in two contrasting ecosystems, a semi 394 enclosed lagoon ecosystem versus an open coastal ecosystem. The four seasons were 395 studied to address the eventual modifications of the microbial community 
composition driven by seasons. It is noteworthy, however, that the four seasons were

397 studied from April 2014 to July 2016, excluding so the possible seasonal succession and 398 the "ecological memory" of the microbial community between two consecutive seasons 399 (Padisák et al., 2010). The two Mediterranean ecosystems exhibited contrasting 400 environmental conditions during the four seasons studied with marked differences in 401 chemical contamination (Table S1, Supplementary materials); the lagoon waters were significantly more contaminated than the offshore waters (Bancon-Montigny et al., 2019; Pringault et al., 2020). According to the concept of pollution-induced community tolerance that can be triggered by the chemical environment and the possible selection of tolerant species (Blanck, 2002), these two contrasting environments allowed testing the hypothesis that the microbial response to chemical contamination would be different in the two sampling sites, with possible consequences for the interactions between the two key players of the marine trophic web.

\subsection{In situ phytoplankton and bacterioplankton diversity}

410 The number of in situ phytoplankton species (129) identified by microscopy was in the 411 same order of magnitude as that observed in similar Mediterranean ecosystems 412 (Draredja et al., 2019; Percopo et al., 2011) or in other coastal regions (Srichandan et al., 2019) using the same counting technique. Similarly, the number of OTUs (19 169 for

414 the in situ database) estimated by the 16S rRNA gene considered as a proxy of the bacterioplankton richness, was comparable to bacterial specific richness estimates determined with similar molecular tools in other coastal ecosystems (Goni-Urriza et al., 2018; Mohapatra et al., 2020). As generally observed in Mediterranean coastal ecosystems (Pulina et al., 2018; Quero et al., 2017), phytoplankton and bacterioplankton diversity exhibited clear seasonal variations in lagoon and offshore waters. Surprisingly, higher phytoplankton diversity indices were observed during 421 spring and fall, seasons where phytoplankton blooms are likely to occur in Mediterranean coastal ecosystems (Ribera d'Alcalà et al., 2004); algal blooms often 423 being concomitant with low phytoplankton diversity (Lehtinen et al., 2017; Livingston, 424 2007). Phytoplankton diversity was significantly higher $(\mathrm{p}<0.05)$ in offshore waters 
425 relative to lagoon waters, contrasting that observed in other lagoons where 426 phytoplankton diversity in the enclosed system can be higher (Srichandan et al., 2019) 427 or equivalent (Minicante et al., 2019) to their adjacent waters. These contrasting results 428 show the particular trophic status played by semi enclosed ecosystems relative to their 429 counterpart adjacent marine waters (Newton et al., 2014), differences that might be 430 explained by the anthropogenic pressure exerted on enclosed systems that can result 431 in a reduction of diversity. Both ecosystems shared common bacterioplankton species 432 (1 739 OTUs) and phytoplankton species (51 species) such as OTUs 17 or 19 affiliated 433 to the SAR 11 clade, the dinoflagellate Heterocapsa minima, or the diatom Cylindrotheca 434 closterium, suggesting connectivity between lagoon and offshore waters (Minicante et 435 al., 2019). Nevertheless, the environmental conditions were sufficiently different to 436 allow the occurrence of distinct phytoplankton communities (48 and 30 species 437 uniquely observed in offshore and lagoon waters, respectively) and bacterioplankton 438 communities (9 033 and 8397 OTUs specifically observed in offshore and lagoon 439 waters, respectively). In fact, despite a large open channel to the coastal sea, the 440 watershed influence and the very long water residence time ( $>200$ days) observed in 441 the Bizerte lagoon (Béjaoui et al., 2017) relative to the offshore adjacent waters $(<20$ 442 days) (Sayol et al., 2013) allows accumulation of nutrients, DOC, and chemical 443 contaminants within the lagoon (Bancon-Montigny et al., 2019; Pringault et al., 2020). 444 Moreover, salinity and temperature variations showed distinct patterns with higher 445 salinity and temperature during spring and winter in offshore waters compared to the 446 lagoon ecosystem, whereas the opposite trends was observed during summer where 447 temperature and salinity values were maximal in the semi enclosed system (Béjaoui et 448 al., 2016; Pringault et al., 2020). The dissimilarities observed for bacterioplankton and 449 phytoplankton communities between lagoon and offshore waters might result in 450 distinct responses to anthropogenic pressure such as chemical contamination.

452 The impact of chemical contamination on bacterioplankton and phytoplankton 453 communities was more marked in offshore waters than in lagoon waters with a clear 
seasonal effect. A reduction of phytoplankton diversity concomitant to changes of phytoplankton structure was observed during spring and fall, especially upon sediment elutriate exposure (CW treatment). As a general rule, the structural changes were less pronounced when the communities were exposed to the artificial mixture of pesticides and TME (ACW treatment) than when exposed to sediment elutriate. The artificial contamination was designed to mimic the concentrations of pesticides and TME observed in sediment elutriate (Bancon-Montigny et al., 2019), but did not include increased levels of other elements such as nutrients, DOC or benthic microorganisms that were present in the sediment elutriate. This artificial cocktail resulted in a significant reduction of metabolic activities involved in the carbon cycle (Pringault et al., 2020, 2016), especially in offshore waters. Nevertheless, the toxic effects observed on microbial metabolic activities were alleviated when the toxic chemical compounds were accompanied by high concentrations of nutrients and DOC, chemical conditions observed in sediment elutriate (Bancon-Montigny et al., 2019). This exogenous supply of nutrients may promote the growth of nutrient limited phytoplankton species, especially during summer and winter, the post bloom periods, resulting in an increase of diversity and structural changes of the community. Similarly, the exogenous DOC supply by sediment elutriate may promote the growth of heterotrophic bacteria (Uchimiya et al., 2016), loosening their dependency on phytoplankton exudates to sustain their carbon requirements.

474 Enclosed systems under anthropogenic pressure, such as lagoons, promote favorable conditions for selective pressure of resistant species to chemical contamination according to the pollution-induced community tolerance concept proposed by Blanck et al. (1988) and illustrated with benthic phototrophic biofilms (Belando et al., 2017) or meiofauna (Boufahja and Semprucci, 2015). Dense populations of the diatom

479 Chaetoceros sp. were observed in the lagoon ecosystem especially during summer, 480 representing up to $68 \%$ of the total relative abundance. The Chaetoceros genus is 481 considered one of the most abundant diatoms in marine phytoplankton (De Luca et 482 al., 2019) and this phytoplankton species has been proposed as a biological indicator 
483 for detecting environmental stress, considering its ability to thrive in contaminated 484 marine environments (Verlecar et al., 2006). In this vein, the Gammaproteobacteria 485 Marinobacterium sp. or Alteromonas sp. were often observed in situ in the lagoon waters 486 with a relative abundance often close to 1\%, and their abundance could reach up 10\% 487 (Alteromonas sp.) in contaminated microcosms, either by sediment elutriate (CW) or by 488 the artificial mixture of pesticides and TME (ACW). The great abundance of 489 Marinobacterium sp. and Alteromonas sp. under chemical contamination is in agreement 490 with previous studies reporting their dominance in bacterial communities exposed to 491 various stressors, including chemical contamination by oil or hydrocarbons (Catania 492 et al., 2015; Dos Santos et al., 2011; Yakimov et al., 2005) or eutrophication (Wang et al., 493 2020). In addition, the great abundance of Alteromonas sp. in the ACW treatment 494 confirms that this species could be used as a bioindicator of metal polluted 495 environments (Selvin et al., 2009). The difference in phytoplankton or bacterioplankton 496 communities observed in offshore and lagoon waters with the possible selection of 497 resistant species in the enclosed ecosystem might affect the interactions between 498 bacterioplankton and phytoplankton, considering that the microalgae-bacteria 499 association is species dependent (Seymour et al., 2017).

\section{$500 \quad 4.3$ Contamination and bacterioplankton-phytoplankton interactions}

501 Phytoplankton-bacterioplankton interactions and the resulting networks were 502 assessed with the Spearman correlation calculated with abundance data, thus allowing 503 detection of positive (mutualism or symbiose) or negative (resource competition, 504 parasitism, or predation) interactions among taxa (Goni-Urriza et al., 2018), bearing in 505 mind the limitations of using co-occurrence as a proxy for ecological interactions 506 (Blanchet et al., 2020; Freilich et al., 2018). This similarity based technique is often 507 employed to construct microbial networks in aquatic ecosystems (Mikhailov et al., 508 2019; Zhu et al., 2018) although more complex modeling approaches allow 509 distinguishing unidirectional ecological interactions (such as amensalism) from 510 bidirectional ecological interactions (such as competition and mutualism) or 
commensalistic association with no negative or positive effects between the considered

512 species (Faust and Raes, 2012).

513 The lagoon ecosystem and its adjacent open waters were characterized by distinct 514 phytoplankton-bacterioplankton interactions. In offshore waters, positive interactions 515 largely dominated over negative interactions (451 positive vs. 113 negative) resulting 516 in a complex bacterio-phytoplankton network. For the lagoon ecosystem, the 517 proportion of negative interactions was higher (227 negative vs. 384 positive) drawing

518 a simpler phytoplankton-bacterioplankton network, involving less bacterial species 519 relative to the offshore situation. A similar tendency was observed in the Venice 520 lagoon, with less interactions within the microbial communities in benthic and pelagic 521 lagoon biotopes relative to the adjacent open waters (Minicante et al., 2019; Quero et 522 al., 2017), suggesting that environmental heterogeneity in these adjacent and 523 connected ecosystems can be strong enough to allow for ecological segregation 524 (Minicante et al., 2019).

525 In both ecosystems, negative interactions were mainly observed in contaminated 526 treatments (CW and ACW) with dinoflagellates whereas positive interactions 527 dominated in control treatments. Negative correlations may indicate competition, 528 inhibition, or predation among taxa. Dinoflagellates are known to produce toxin 529 compounds resulting in allelopathic interactions with bacteria through cell lysis, 530 blistering, or growth inhibition (Legrand et al., 2003; Paul et al., 2007). Nevertheless, 531 dinoflagellates can also be specifically associated through positive interactions with 532 particular bacterial species, such as Roseobacter sp. or Marinobacter sp. (Jasti et al., 2005). 533 In contrast, bacterial interactions with Cryptophyta were dominated by positive 534 correlations, especially in offshore waters in control conditions, as also observed in 535 freshwater ecosystems where this phytoplankton group can form dense blooms 536 (Mikhailov et al., 2019) knowing that this mixotrophic species can also be considered 537 as bacterivores (Grujcic et al., 2018). Interestingly, this mixotrophic regime might be 538 controlled by the presence of contaminants, since the negative interactions between 539 Cryptophyta and prokaryotes in ACW and CW treatments suggest an increase of 
540 predation, as previously demonstrated by Losey \& Denno (1999). Chemical

541 contamination as well as sediment elutriate provoked significant changes in bacteria-

542 phytoplankton interactions resulting in a simplification of the microbial pelagic 543 network. A similar simplification effect of oil contamination was also observed in soils

544 with a reduction of interactions and connectivity among bacteria (Liang et al., 2016).

545 Anthropogenic stressors are known to impact the functioning of the aquatic primary 546 producers and consequently, primary production is more sensitive to chemical 547 contamination than respiration (Johnston et al., 2015). Reduction of phytoplankton 548 biomass upon chemical contamination has been observed with a wide range of 549 contaminants including metal (Rochelle-Newall et al., 2008), pesticides (Pelletier et al., 550 2006), plastic derivatives (M'Rabet et al., 2019), PAHs (Ben Othman et al., 2018; Hjorth 551 et al., 2008, 2007), or with a contaminant mixture (Pringault et al., 2020). These 552 inhibitory effects of chemical contaminants on the primary producers alter the 553 synchrony between the phytoplankton and bacterioplankton (Goni-Urriza et al., 2018).

554 Indeed, a reduction of phytoplankton biomass upon chemical stress, as observed in 555 the ACW treatment, will also reduce the interactions with bacterioplankton, 556 considering the interdependency observed between both compartments, especially in 557 open waters where phytoplankton and bacterioplankton can be strongly coupled 558 (Morán et al., 2002; Pringault et al., 2020).

559 In contrast to the artificial chemical contamination with TME and pesticides, exposure 560 to sediment elutriate provoked a strong stimulation of phytoplankton biomass 561 (Pringault et al., 2020) concomitant with a shift in the phytoplankton community 562 structure, especially in offshore waters. The important release of dissolved organic 563 matter (DOM) and nutrients from sediment resuspension (Bancon-Montigny et al., 564 2019) alleviated the toxic effects of chemical contaminants present in the sediment 565 elutriate. Interestingly, the stimulation of phytoplankton biomass (Pringault et al., 566 2020) was concomitant with a reduction of phytoplankton diversity, leading to a 567 simplification of the microbial network in lagoon and offshore waters. Phytoplankton 568 blooms are known to strongly impact the interactions with bacterioplankton (Teeling 
et al., 2012), especially in the case of harmful algal bloom (Paerl and Otten, 2013). A

570 reduction of phytoplankton diversity during blooms has been already observed 571 (Livingston, 2007), with no negligible impacts for the diversity of the associated

572

573

574

575

576

577

578

579

580

581

582

583

584

585

586

587

588

589

590

591

592

593

594 The present study clearly showed that a semi-enclosed ecosystem and its adjacent bacterial community (Wemheuer et al., 2014), and for the interactions among phytoplankton species depending on which taxa dominates the bloom (Escalas et al., 2019). With phytoplankton and bacteria associations being species dependent (Grossart et al., 2005; Seymour et al., 2017), a shift (natural or anthropogenic triggered) in the phytoplankton community structure can impact the bacterial association, as differences in the phytoplankton community structure can lead to changes in quality and quantity of exuded organic matter that can be mineralized by bacteria for their growth (Kent et al., 2007, 2004; Liu et al., 2014). In addition, sediment resuspension provoked strong DOM release but also a significant increase in bacterial biomass, both conditions resulting in stimulation of the heterotrophic metabolism (Pringault et al., 2020). The simplified networks observed in CW treatments relative to the control clearly showed that this external supply of exogenous bacteria and dissolved organic matter decreases the interdependency between phytoplankton and bacterioplankton. Bacteria (indigenous and exogenous) have access to an external carbon source, so loosening their dependency on phytoplankton exudates to sustain their carbon demand, while interactions among bacteria increased. Increasing bacterial cooperation and association is important to allow biodegradation of recalcitrant biopolymers (Ebrahimi et al., 2019) such as those found in sediment-derived DOM, a complex mixture of organic compounds with different lability properties (Wu et al., 2018). Such a "priming effect" mechanism was widely reported in soils but rarely in marine waters (Bianchi, 2011; Blanchet et al., 2017).

\section{Conclusion}

open waters exhibited distinct phytoplankton and bacterioplankton communities that differ depending on season. These differences result in specific networks, suggesting 
597

598

599

600

601

602

603

604

605

606

607

608

609

610

611

612

613

614

615

616

617

618

619

620

621

622

623

that environmental heterogeneity can be strong enough to allow for ecological segregation despite sea-lagoon connectivity. Offshore waters were characterized by a complex phytoplankton-bacterioplankton network dominated by positive interactions between primary producers and bacteria, while the semi-enclosed ecosystem harbored a simplified network where negative interactions were more prevalent. Chemical contamination resulted in a decrease of phytoplankton biomass especially during the bloom periods (spring and autumn) in offshore waters, leading to a simplification of the phytoplankton-bacterioplankton network dominated by negative interactions. Nutrients and DOM released by sediment resuspension alleviated the toxic effects of chemical compounds (mainly pesticides and TME) present in the elutriate, provoking stimulation of phytoplankton and bacterial biomass concomitant with a significant shift in the phytoplankton community structure and reduction of phytoplankton diversity. These structural changes favored the loosening of the bacteria-phytoplankton coupling (Pringault et al., 2020) with strong consequences for the trophic web and ecosystem functioning.

\section{Acknowledgments}

This study was supported by the RISCO project (ANR-13-CESA-0001), funded by the French National Agency for Research (ANR) and by the Joint International Laboratory COSYS-Med. English grammar and syntax of the manuscript were revised by ProofReading-Service.com.

\section{Cited references}

Amin, S.A., Parker, M.S., Armbrust, E. V., 2012. Interactions between Diatoms and Bacteria. Microbiol. Mol. Biol. Rev. 76, 667-684. https://doi.org/10.1128/mmbr.00007-12

Azam, F., Fenchel, T., Field, J., Gray, J., Meyer-Reil, L., Thingstad, F., 1983. The Ecological Role of Water-Column Microbes in the Sea. Mar. Ecol. Prog. Ser. 10, 257-263. https://doi.org/10.3354/meps010257 
624 Bancon-Montigny, C., Gonzalez, C., Delpoux, S., Avenzac, M., Spinelli, S., Mhadhbi, T., Mejri, K., Hlaili, A.S., Pringault, O., 2019. Seasonal changes of chemical contamination in coastal waters during sediment resuspension. Chemosphere 235, 651-661. https://doi.org/10.1016/j.chemosphere.2019.06.213

Barhoumi, B., LeMenach, K., Devier, M.H., Ben Ameur, W., Etcheber, H., Budzinski, H., Cachot, J., Driss, M.R., 2014a. Polycyclic aromatic hydrocarbons (PAHs) in

Barhoumi, B., LeMenach, K., Devier, M.H., El Megdiche, Y., Hammami, B., Ben Ameur, W., Ben Hassine, S., Cachot, J., Budzinski, H., Driss, M.R., 2014b. Distribution and ecological risk of polychlorinated biphenyls (PCBs) and organochlorine pesticides

Béjaoui, B., Armi, Z., Ottaviani, E., Barelli, E., Gargouri-Ellouz, E., Chérif, R., Turki, S., (OCPs) in surface sediments from the Bizerte lagoon, Tunisia. Environ. Sci. Pollut. Res. 21, 6290-6302. https://doi.org/10.1007/s11356-013-1709-7

Solidoro, $C$, Aleya, L 2016. Random Forest model and TRIX used in combination to assess and diagnose the trophic status of Bizerte Lagoon, southern Mediterranean. Ecol. Indic. 71 , 293-301. https://doi.org/10.1016/j.ecolind.2016.07.010

Bejaoui, B., Solidoro, C., Harzallah, A., Chevalier, C., Chapelle, A., Zaaboub, N., Aleya, L., 2017.3D modeling of phytoplankton seasonal variation and nutrient budget in a southern Mediterranean Lagoon. Mar. Pollut. Bull. 114, 962-976. https://doi.org/10.1016/j.marpolbul.2016.11.001

Belando, M.D., Marín, A., Aboal, M., García-Fernández, A.J., Marín-Guirao, L., 2017. Combined in situ effects of metals and nutrients on marine biofilms: Shifts in the diatom assemblage structure and biological traits. Sci. Total Environ. 574, 381-389. https://doi.org/10.1016/j.scitotenv.2016.08.197

Ben Othman, H., Lanouguère, É., Got, P., Sakka Hlaili, A., Leboulanger, C., 2018. Structural and functional responses of coastal marine phytoplankton 
communities to PAH mixtures. Chemosphere 209, 908-919. https://doi.org/10.1016/j.chemosphere.2018.06.153

Ben Said, O., Goni-Urriza, M., El Bour, M., Aissa, P., Duran, R., 2010. Bacterial Community Structure of Sediments of the Bizerte Lagoon (Tunisia), a Southern Mediterranean Coastal Anthropized Lagoon. Microb. Ecol. 59, 445-456.

Berard, A., Pelte, T., Druart, J.C., Bérard, A., Pelte, T., Druart, J.C., 1999. Seasonal

Berglund, J., Müren, U., Båmstedt, U., Andersson, A., 2007. Efficiency of a 663 phytoplankton-based and a bacteria-based food web in a pelagic marine system. variations in the sensitivity of Lake Geneva phytoplankton community structure to atrazine. Arch. für Hydrobiol. 145, 277-295. https://doi.org/10.1127/archivhydrobiol/145/1999/277

$$
\text { Limnol. Oceanogr. 52, 121-131. https://doi.org/10.4319/lo.2007.52.1.0121 }
$$

Bianchi, T.S., 2011. The role of terrestrially derived organic carbon in the coastal ocean: A changing paradigm and the priming effect. Proc. Natl. Acad. Sci. U. S. A. 108, 19473-19481. https://doi.org/10.1073/pnas.1017982108

Blanchet, F.G., Cazelles, K., Gravel, D., 2020. Co-occurrence is not evidence of ecological interactions. Ecol. Lett. 23, 1050-1063. https://doi.org/10.1111/ele.13525

Blanchet, M., Pringault, O., Panagiotopoulos, C., Lefèvre, D., Charrière, B., Ghiglione, J.F., Fernandez, C., Aparicio, F.L., Marrasé, C., Catala, P., Oriol, L., Caparros, J., Joux, F., 2017. When riverine dissolved organic matter (DOM) meets labile DOM in coastal waters: changes in bacterial community activity and composition. Aquat. Sci. 79, 27-43. https://doi.org/10.1007/s00027-016-0477-0

Blanck, H., 2002. A critical review of procedures and approaches used for assessing pollution-induced community tolerance (PICT) in biotic communities. Hum. Ecol. Risk Assess. 8, 1003-1034.

Blanck, H., Wängberg, S.A., Molander, S., 1988. Pollution induced community tolerance-a new ecotoxicological tool, in: Cairns, J.J., Pratt, J.R. (Eds.), Functional Testing of Aquatic Biota for Estimating Hazards of Chemicals. American Society for Testing Materials, Philadelphia, PA, pp. 219-230. 
Bonnet, C., Babut, M., Ferard, J.F., Martel, L., Garric, J., 2000. Assessing the potential toxicity of resuspended sediment. Environ. Toxicol. Chem. 19, 1290-1296.

Boufahja, F., Semprucci, F., 2015. Stress-induced selection of a single species from an entire meiobenthic nematode assemblage: is this possible using iron enrichment and does pre-exposure affect the ease of the process? Environ. Sci. Pollut. Res. 22, 1979-1998. https://doi.org/10.1007/s11356-014-3479-2

Carr, R.S., Chapman, D.C., 1995. Comparison of methods for conducting marine and estuarine sediment porewater toxicity tests - extraction, storage, and handling techniques. Arch. Environ. Contam. Toxicol. 28, 69-77.

Catania, V., Santisi, S., Signa, G., Vizzini, S., Mazzola, A., Cappello, S., Yakimov, M.M.M., Quatrini, P., 2015. Intrinsic bioremediation potential of a chronically polluted marine coastal area. Mar. Pollut. Bull. 99, 138-149. https://doi.org/10.1016/j.marpolbul.2015.07.042

Cirri, E., Pohnert, G., 2019. Algae-bacteria interactions that balance the planktonic microbiome. New Phytol. https://doi.org/10.1111/nph.15765

Cole, J.J., 1982. Interactions between bacteria and algae in aquatic ecosystems. Annu. $\begin{array}{lllll}\text { Rev. } & \text { Ecol. } & \text { Syst. } & \text { Vol. } & 13\end{array}$ https://doi.org/10.1146/annurev.es.13.110182.001451

De Luca, D., Kooistra, W.H.C.F., Sarno, D., Gaonkar, C.C., Piredda, R., 2019. Global distribution and diversity of Chaetoceros (Bacillariophyta, Mediophyceae): integration of classical and novel strategies. PeerJ 1-23. https://doi.org/10.7717/peerj.7410

Dos Santos, H.F., Cury, J.C., do Carmo, F.L., Dos Santos, A.L., Tiedje, J., van Elsas, J.D., Rosado, A.S., Peixoto, R.S., 2011. Mangrove bacterial diversity and the impact of oil contamination revealed by pyrosequencing: Bacterial proxies for oil pollution. PLoS One 6. https://doi.org/10.1371/journal.pone.0016943

Draredja, M.A., Frihi, H., Boualleg, C., Gofart, A., Abadie, E., Laabir, M., 2019. Seasonal variations of phytoplankton community in relation to environmental factors in a protected meso-oligotrophic southern Mediterranean marine ecosystem (Mellah 
lagoon, Algeria) with an emphasis of HAB species. Environ. Monit. Assess. 191, 603. https://doi.org/10.1007/s10661-019-7708-5

Ebrahimi, A., Schwartzman, J., Cordero, O.X., 2019. Cooperation and spatial selforganization determine rate and efficiency of particulate organic matter degradation in marine bacteria. Proc. Natl. Acad. Sci. U. S. A. 116, 23309-23316. https://doi.org/10.1073/pnas.1908512116

Escalas, A., Catherine, A., Maloufi, S., Cellamare, M., Hamlaoui, S., Yéprémian, C., Louvard, C., Troussellier, M., Bernard, C., 2019. Drivers and ecological consequences of dominance in periurban phytoplankton communities using networks approaches. Water Res. 163 , 114893. https://doi.org/10.1016/j.watres.2019.114893

Faust, K., Raes, J., 2012. Microbial interactions: from networks to models. Nat. Rev. Microbiol. 10, 538-550. https://doi.org/10.1038/nrmicro2832

Fouilland, E., Floc'h, E.L. Le, Brennan, D., Bell, E.M.M., Lordsmith, S.L.L., Mcneill, S., Mitchell, E., Brand, T.D.D., García-Martín, E.E.E., Leakey, R.J.G.G.J.G., 2018a. Assessment of bacterial dependence on marine primary production along a northern latitudinal gradient. FEMS Microbiol. Ecol. 94, 150. https://doi.org/10.1093/femsec/fiy150

Fouilland, E., Galès, A., Beaugelin, I., Lanouguère, É., Pringault, O., Leboulanger, C., $2018 \mathrm{~b}$. Influence of bacteria on the response of microalgae to contaminant mixtures. $\quad$ Chemosphere 211, 449-455. https://doi.org/10.1016/j.chemosphere.2018.07.161

Fouilland, E., Tolosa, I., Bonnet, D., Bouvier, C., Bouvier, T., Bouvy, M., Got, P., Le Floc'h, E., Mostajir, B., Roques, C., Sempéré, R., Sime-Ngando, T., Vidussi, F., 2014. Bacterial carbon dependence on freshly produced phytoplankton exudates under different nutrient availability and grazing pressure conditions in coastal marine waters. FEMS Microbiol. Ecol. 87, 757-769. https://doi.org/10.1111/15746941.12262

Freilich, M.A., Wieters, E., Broitman, B.R., Marquet, P.A., Navarrete, S.A., 2018. Species 
co-occurrence networks: Can they reveal trophic and non-trophic interactions in ecological communities? Ecology 99, 690-699. https://doi.org/10.1002/ecy.2142

Goni-Urriza, M., Moussard, H., Lafabrie, C., Carre, C., Bouvy, M., Sakka Hlaili, A.,

743

744

745

746 Pringault, O., 2018. Consequences of contamination on the interactions between phytoplankton and bacterioplankton. Chemosphere 195. https://doi.org/10.1016/j.chemosphere.2017.12.053

Gregorio, V., Buchi, L., Anneville, O., Rimet, F., Bouchez, A., Chevre, N., 2012. Risk of herbicide mixtures as a key parameter to explain phytoplankton fluctuation in a great lake: The case of Lake Geneva, Switzerland. Ecotoxicology 21, 2306-2318. https://doi.org/10.1007/s10646-012-0987-z

Grossart, H.P., Levold, F., Allgaier, M., Simon, M., Brinkhoff, T., 2005. Marine diatom species harbour distinct bacterial communities. Environ. Microbiol. 7, 860-873. https://doi.org/10.1111/j.1462-2920.2005.00759.x

Grossart, H.P., Simon, M., 2007. Interactions of planktonic algae and bacteria: Effects on algal growth and organic matter dynamics. Aquat. Microb. Ecol. 47, 163-176. https://doi.org/10.3354/ame047163

Grujcic, V., Nuy, J.K., Salcher, M.M., Shabarova, T., Kasalicky, V., Boenigk, J., Jensen, M., Simek, K., 2018. Cryptophyta as major bacterivores in freshwater summer plankton. ISME J. 12, 1668-1681. https://doi.org/10.1038/s41396-018-0057-5

Hill, T.C.J.J., Walsh, K.A., Harris, J.A., Moffett, B.F., 2003. Using ecological diversity measures with bacterial communities. FEMS Microbiol. Ecol. 43, 1-11. https://doi.org/10.1016/S0168-6496(02)00449-X

Hjorth, M., Forbes, V.E., Dahllof, I., 2008. Plankton stress responses from PAH exposure and nutrient enrichment. Mar. Ecol. Ser. 363, 121-130.

Hjorth, M., Vester, J., Henriksen, P., Forbes, V., Dahllof, I., 2007. Functional and structural responses of marine plankton food web to pyrene contamination. Mar. Ecol. Ser. 338, 21-31.

Hoppe, H.G., Breithaupt, P., Walther, K., Koppe, R., Bleck, S., Sommer, U., Jürgens, K., 2008. Climate warming in winter affects the coupling between phytoplankton and 
bacteria during the spring bloom: A mesocosm study. Aquat. Microb. Ecol. 51, 105-115. https://doi.org/10.3354/ame01198

771

772

773

774

775

776

777

778

779

780

781

782

783

784

785

786

787

788

789

790

791

792

793

794

795

796

797

Hoppenrath, M., Elbrachter, M., Drebes, G., 2009. Marine phytoplankton: Selected Microphytoplankton Species from the North Sea Around Helgoland and Sylt. Kleine Serckenerg - Reihe 49, E. Schweizerbart Science Publishers, Stuttgart, Germany.

Hornick, T., Bach, L.T., Crawfurd, K.J., Spilling, K., Achterberg, E.P., Woodhouse, J.N., Schulz, K.G., Brussaard, C.P.D., Riebesell, U., Grossart, H.P., 2017. Ocean acidification impacts bacteria-phytoplankton coupling at low-nutrient conditions. Biogeosciences 14, 1-15. https://doi.org/10.5194/bg-14-1-2017

Jasti, S., Sieracki, M.E., Poulton, N.J., Giewat, M.W., Rooney-Varga, J.N., 2005. Phylogenetic diversity and specificity of bacteria closely associated with Alexandrium spp. and other phytoplankton. Appl. Environ. Microbiol. 71, 34833494. https://doi.org/10.1128/AEM.71.7.3483-3494.2005

Johnston, E.L., Mayer-Pinto, M., Crowe, T.P., 2015. Chemical contaminant effects on marine ecosystem functioning. J. Appl. Ecol. https://doi.org/10.1111/13652664.12355

Kent, A.D., Jones, S.E., Yannarell, A.C., Graham, J.M., Lauster, G.H., Kratz, T.K., Triplett, E.W., 2004. Annual patterns in bacterioplankton community variability in a humic lake. Microb. Ecol. 48, 550-560. https://doi.org/10.1007/s00248-0040244-y

Kent, A.D., Yannarell, A.C., Rusak, J.A., Triplett, E.W., McMahon, K.D., 2007. Synchrony in aquatic microbial community dynamics. Isme J. 1, 38-47. https://doi.org/10.1038/ismej.2007.6

Kraberg, A., Baumann, M., Dürselen, C.-D., 2010. Coastal phytoplankton. Photo guide for Northern European Seas. Verlag, Munchen Germany.

Legendre, P., Legendre, L., 1998. Numerical Ecology. Elsevier, Amsterdam.

Legrand, C., Rengefors, K., Fistarol, G.O., Granéli, E., 2003. Allelopathy in phytoplankton - Biochemical, ecological and evolutionary aspects. Phycologia 42, 
799 Lehtinen, S., Tamminen, T., Ptacnik, R., Andersen, T., 2017. Phytoplankton species richness, evenness, and production in relation to nutrient availability and imbalance. Limnol. Oceanogr. 62, 1393-1408. https://doi.org/10.1002/lno.10506

803

804

Levy, J.L., Stauber, J.L., Wakelin, S.A., Jolley, D.F., 2009. The effect of bacteria on the sensitivity of microalgae to copper in laboratory bioassays. Chemosphere 74,

806 1266-1274. https://doi.org/10.1016/j.chemosphere.2008.10.049

Liang, Y., Zhao, H., Deng, Y., Zhou, J., Li, G., Sun, B., 2016. Long-term oil 808

Liu, L., Yang, J., Lv, H., Yu, Z., 2014. Synchronous dynamics and correlations between 809 bacteria and phytoplankton in a subtropical drinking water reservoir. FEMS Microbiol. Ecol. 90, 126-138. https://doi.org/10.1111/1574-6941.12378

Livingston, R.J.J., 2007. Phytoplankton bloom effects on a Gulf estuary: Water quality

Losey, J.E., Denno, R.F., 1999. Factors facilitating synergistic predation: the central role changes and biological response, in: Ecological Applications. pp. 110-128. https://doi.org/10.1890/05-0769.1 of synchrony. Ecol. Appl. 9, 378. https://doi.org/10.2307/2641125

M’Rabet, C., Kéfi-Daly Yahia, O., Couet, D., Gueroun, S.K.M., Pringault, O., 2019. Consequences of a contaminant mixture of bisphenol A (BPA) and di-(2ethylhexyl) phthalate (DEHP), two plastic-derived chemicals, on the diversity of coastal phytoplankton. Mar. Pollut. Bull. 138, 385-396. https://doi.org/10.1016/j.marpolbul.2018.11.035

Mhadhbi, T., Pringault, O., Nouri, H., Spinelli, S., Beyrem, H., Gonzalez, C., 2019. Evaluating polar pesticide pollution with a combined approach: a survey of agricultural practices and POCIS passive samplers in a Tunisian lagoon watershed. Environ. Sci. Pollut. Res. 26. https://doi.org/10.1007/s11356-018-3552-3

Mikhailov, I.S., Bukin, Y.S., Zakharova, Y.R., Usoltseva, M. V., Galachyants, Y.P., Sakirko, M. V., Blinov, V. V., Likhoshway, Y. V., 2019. Co-occurrence patterns 
between phytoplankton and bacterioplankton across the pelagic zone of Lake Baikal during spring. J. Microbiol. 57, 252-262. https://doi.org/10.1007/s12275-019$8531-y$

Minicante, S.A., Piredda, R., Quero, G.M., Finotto, S., Bernardi Aubry, F., Bastianini, M., Pugnetti, A., Zingone, A., 2019. Habitat Heterogeneity and Connectivity: Effects on the Planktonic Protist Community Structure at Two Adjacent Coastal Sites (the Lagoon and the Gulf of Venice, Northern Adriatic Sea, Italy) Revealed by Metabarcoding. Front. Microbiol. 10. https://doi.org/10.3389/fmicb.2019.02736

Mohapatra, M., Behera, P., Kim, J.Y., Rastogi, G., 2020. Seasonal and spatial dynamics of bacterioplankton communities in a brackish water coastal lagoon. Sci. Total Environ. 705. https://doi.org/10.1016/j.scitotenv.2019.134729

Morán, X.A.G., Ducklow, H.W., Erickson, M., 2013. Carbon fluxes through estuarine bacteria reflect coupling with phytoplankton. Mar. Ecol. Prog. Ser. 489, 75-85. https://doi.org/10.3354/meps10428

Morán, X.A.G., Estrada, M., Gasol, J.M., Pedros-Alio, C., 2002. Dissolved primary 842 production and the strength of phytoplankton bacterioplankton coupling in contrasting marine regions. Microb. Ecol. 44, 217-223.

Newton, A., Icely, J., Cristina, S., Brito, A., Cardoso, A.C., Colijn, F., Riva, S.D., Gertz, 845 F., Hansen, J.W., Holmer, M., Ivanova, K., Leppäkoski, E., Canu, D.M., Mocenni, C., Mudge, S., Murray, N., Pejrup, M., Razinkovas, A., Reizopoulou, S., PérezRuzafa, A., Schernewski, G., Schubert, H., Carr, L., Solidoro, C., PierluigiViaroli, Zaldívar, J.-M.M., Viaroli, P., Zaldívar, J.-M.M., 2014. An overview of ecological status, vulnerability and future perspectives of European large shallow, semienclosed coastal systems, lagoons and transitional waters. Estuar. Coast. Shelf Sci. 140, 95-122. https://doi.org/10.1016/j.ecss.2013.05.023

Padisák, J., Hajnal, É., Krienitz, L., Lakner, J., Üveges, V., 2010. Rarity, ecological memory, rate of floral change in phytoplankton-and the mystery of the Red Cock. Hydrobiologia 653, 45-64. https://doi.org/10.1007/s10750-010-0344-2

Paerl, H.W., Otten, T.G., 2013. Harmful Cyanobacterial Blooms: Causes, 
Consequences, and Controls. Microb. Ecol. 65, 995-1010. https://doi.org/10.1007/s00248-012-0159-y

858 Paul, V.J., Arthur, K.E., Ritson-Williams, R., Ross, C., Sharp, K., 2007. Chemical 859 defenses: From compounds to communities, in: Biological Bulletin. Marine Biological Laboratory, pp. 226-251. https://doi.org/10.2307/25066642

Pelletier, É., Sargian, P., Payet, J., Demers, S., 2006. Ecotoxicological Effects of 863 Combined UVB and Organic Contaminants in Coastal Waters: A Review. Photochem. Photobiol. 82, 981. https://doi.org/10.1562/2005-09-18-ra-688.1

Percopo, I., Siano, R., Cerino, F., Sarno, D., Zingone, A., 2011. Phytoplankton diversity 866 during the spring bloom in the northwestern Mediterranean Sea. Bot. Mar. 54, 243-267. https://doi.org/10.1515/BOT.2011.033

Prieto, A., Barber-Lluch, E., Hernández-Ruiz, M., Martínez-García, S., Fernández, E., 868 Teira, E., 2015. Assessing the role of phytoplankton-bacterioplankton coupling in the response of microbial plankton to nutrient additions. J. Plankton Res. 38, 5563. https://doi.org/10.1093/plankt/fbv101

Pringault, O., Bouvy, M., Carre, C., Fouilland, E., Meddeb, M., Mejri, K., Leboulanger, C., Hlaili, A.S., Sakka Hlaili, A., 2020. Impacts of chemical contamination on bacterio-phytoplankton coupling. Chemosphere 257, in press. https://doi.org/10.1016/j.chemosphere.2020.127165

Pringault, O., Lafabrie, C., Avezac, M., Bancon-Montigny, C., Carre, C., Chalghaf, M., Delpoux, S., Duvivier, A., Elbaz-Poulichet, F., Gonzalez, C., Got, P., Leboulanger, C., Spinelli, S., Sakka Hlaili, A., Bouvy, M., 2016. Consequences of contaminant mixture on the dynamics and functional diversity of bacterioplankton in a southwestern Mediterranean coastal ecosystem. Chemosphere 144, 1060-1073. https://doi.org/10.1016/j.chemosphere.2015.09.093 phytoplankton size structure in relation to environmental variables in three 
Quero, G.M., Perini, L., Pesole, G., Manzari, C., Lionetti, C., Bastianini, M., Marini, M., Luna, G.M., 2017. Seasonal rather than spatial variability drives planktonic and benthic bacterial diversity in a microtidal lagoon and the adjacent open sea. Mol. Ecol. 26, 5961-5973. https://doi.org/10.1111/mec.14363

Ramette, A., 2007. Multivariate analyses in microbial ecology. FEMS Microbiol. Ecol. $62,142-160$.

Ribera d'Alcalà, M., Conversano, F., Corato, F., Licandro, P., Mangoni, O., Marino, D., Mazzocchi, M.G., Modigh, M., Montresor, M., Nardella, M., Saggiomo, V., Sarno, D., Zingone, A., 2004. Seasonal patterns in plankton communities in a pluriannual time series at a coastal Mediterranean site (Gulf of Naples): an attempt to discern recurrences and trends. Sci. Mar. 68, 65-83. https://doi.org/10.3989/scimar.2004.68s165

Rochelle-Newall, E.J., Delesalle, B., Mari, X., Rouchon, C., Torréton, J.-P., Pringault, O., 2008. Zinc induces shifts in microbial carbon flux in tropical coastal environments. Aquat. Microb. Ecol. 52. https://doi.org/10.3354/ame01212

Russo, D.A., Couto, N., Beckerman, A.P., Pandhal, J., 2016. A Metaproteomic Analysis of the Response of a Freshwater Microbial Community under Nutrient Enrichment. Front. Microbiol. 7. https://doi.org/10.3389/fmicb.2016.01172

Sakka Hlaili, A., Grami, B., Mabrouk, H.H., Gosselin, M., Hamel, D., 2007. Phytoplankton growth and microzooplankton grazing rates in a restricted Mediterranean lagoon (Bizerte Lagoon, Tunisia). Mar. Biol. 151, 767-783.

Sakka Hlaili, A., Niquil, N., Legendre, L., 2014. Planktonic food webs revisited: Reanalysis of results from the linear inverse approach. Prog. Oceanogr. 120, 216229. https://doi.org/http://dx.doi.org/10.1016/j.pocean.2013.09.003

Sayol, J.M., Orfila, A., Simarro, G., Lõpez, C., Renault, L., Galán, A., Conti, D., 2013. Sea surface transport in the Western mediterranean sea: A lagrangian perspective. J. Geophys. Res. Ocean. 118, 6371-6384. https://doi.org/10.1002/2013JC009243

Selvin, J., Shanmugha Priya, S., Seghal Kiran, G., Thangavelu, T., Sapna Bai, N., 2009. Sponge-associated marine bacteria as indicators of heavy metal pollution. 
Seymour, J.R., Amin, S.A., Raina, J.-B., Stocker, R., 2017. Zooming in on the phycosphere: the ecological interface for phytoplankton-bacteria relationships. Nat. Microbiol. 2, 17065. https://doi.org/10.1038/nmicrobiol.2017.65

Shannon, P., Markiel, A., Ozier, O., Baliga, N.S., Wang, J.T., Ramage, D., Amin, N., Schwikowski, B., Ideker, T., 2003. Cytoscape: A software Environment for integrated models of biomolecular interaction networks. Genome Res. 13, 24982504. https://doi.org/10.1101/gr.1239303

Srichandan, S., Baliarsingh, S.K., Prakash, S., Lotliker, A.A., Parida, C., Sahu, K.C., 2019. Seasonal dynamics of phytoplankton in response to environmental variables in contrasting coastal ecosystems. Environ. Sci. Pollut. Res. 26, 12025-12041. https://doi.org/10.1007/s11356-019-04569-5

Teeling, H., Fuchs, B.M., Becher, D., Klockow, C., Gardebrecht, A., Bennke, C.M., 927 Kassabgy, M., Huang, S., Mann, A.J., Waldmann, J., Weber, M., Klindworth, A.,

Tomas, C.R., Halse, G.R., Syvertsen, E.E., Steidinger, K.A., Tangen, K., Throndsen, J., Heimdal, B.R., 1997. Identifying marine phytoplankton. Academic Press.

Triki, H.Z., Laabir, M., Lafabrie, C., Malouche, D., Bancon-Montigny, C., Gonzalez, C., 937 Otto, A., Lange, J., Bernhardt, J., Reinsch, C., Hecker, M., Peplies, J., Bockelmann, F.D., Callies, U., Gerdts, G., Wichels, A., Wiltshire, K.H., Glöckner, F.O., Schweder, T., Amann, R., 2012. Substrate-controlled succession of marine bacterioplankton populations induced by a phytoplankton bloom. Science (80-. ). 336, 608-611. https://doi.org/10.1126/science.1218344

Deidun, A., Pringault, O., Daly-Yahia, O.K., 2017. Do the levels of industrial pollutants influence the distribution and abundance of dinoflagellate cysts in the recently-deposited sediment of a Mediterranean coastal ecosystem? Sci. Total Environ. 595. https://doi.org/10.1016/j.scitotenv.2017.03.183

Uchimiya, M., Motegi, C., Nishino, S., Kawaguchi, Y., Inoue, J., Ogawa, H., Nagata, T., 2016. Coupled response of bacterial production to a wind-induced fall phytoplankton bloom and sediment resuspension in the chukchi sea shelf, 
944 Utermöhl, H., 1958. Zur Vervollkommnung der quantitativen Phytoplankton-Method. 945 Int. Ver. Theor. Angew. Limnol. 9, 1-39.

946 Verlecar, X.N., Desai, S.R., Sarkar, A., Dalal, S.G., 2006. Biological indicators in relation 947 to coastal pollution along Karnataka coast, India. Water Res. 40, 3304-3312. 948

Viličić, D., 2014. Ecology and Composition of Phytoplankton in the Adriatic Sea. Koeltz Scientific Books.

Wang, J., Lu, J., Zhang, Y., Wu, J., 2020. Microbial ecology might serve as new indicator 952

Wemheuer, B., Güllert, S., Billerbeck, S., Giebel, H.A.A., Voget, S., Simon, M., Daniel, R., 2014. Impact of a phytoplankton bloom on the diversity of the active bacterial community in the southern North Sea as revealed by metatranscriptomic

Wu, X., Wu, L., Liu, Y., Zhang, P., Li, Q., Zhou, J., Hess, N.J., Hazen, T.C., Yang, W., Chakraborty, R., 2018. Microbial interactions with dissolved organic matter drive carbon dynamics and community succession. Front. Microbiol. 9. https://doi.org/10.3389/fmicb.2018.01234

Yakimov, M.M., Denaro, R., Genovese, M., Cappello, S., D'Auria, G., Chernikova, T.N., Timmis, K.N., Golyshin, P.N., Giluliano, L., 2005. Natural microbial diversity in

Yoch, D.C., 2002. Dimethylsulfoniopropionate: Its sources, role in the marine food web, and biological degradation to dimethylsulfide. Appl. Environ. Microbiol. https://doi.org/10.1128/AEM.68.12.5804-5815.2002 
972 Zhu, J., Hong, Y., Zada, S., Hu, Z., Wang, H., 2018. Spatial variability and coacclimation 973 of Phytoplankton and bacterioplankton communities in the Pearl River Estuary, 974 China. Front. Microbiol. 9. https://doi.org/10.3389/fmicb.2018.02503

975 Zrafi-Nouira, I., Khedir-Ghenim, Z., Bahri, R., Cheraeif, I., Rouabhia, M., Saidane976 Mosbahi, D., 2009. Hydrocarbons in Seawater and Water Extract of Jarzouna977 Bizerte Coastal of Tunisia (Mediterranean Sea): Petroleum Origin Investigation 978 Around Refinery Rejection Place. Water Air Soil Pollut. 202, 19-31.

979 Zrafi-Nouira, I., Khedir-Ghenim, Z., Zrafi, F., Bahri, R., Cheraeif, I., Rouabhia, M., 980 Saidane-Mosbahi, D., 2008. Hydrocarbon pollution in the sediment from the 981 Jarzouna-Bizerte coastal area of Tunisia (Mediterranean Sea). Bull. Environ. $982 \quad$ Contam. Toxicol. 80, 566-572. 
985 Figure 1: Relative abundances of groups of phytoplankton and bacterioplankton observed in situ 986 in the two sampling stations during the four seasons of the study.

988 Figure 2: Relative abundances of groups of phytoplankton and bacterioplankton observed at the 989 end of the microcosm incubation as a function of treatments during the four seasons. C: Control, ACW: Artificial Contaminated Water and CW: Contaminated Water with sediment elutriate.

Figure 5: Simplified network between phytoplankton groups and bacterial OTUs (indicated by numbers) in Lagoon station as a function of microcosm treatments. Green lines indicate significant $(p<0.05)$ positive correlations (Spearman) and red lines indicate significant $(\mathrm{p}<0.05)$ negative correlations. Solid lines indicate bacterial interactions with other OTUs and with phytoplankton groups, dotted lines indicate interactions between phytoplankton groups. Only correlations $>|0.8|$ are indicated. C: Control, ACW: Artificial Contaminated Water and CW: Contaminated Water with sediment elutriate. See materials and methods for more details.

Figure 6: Simplified network between phytoplankton groups and bacterial OTUs (indicated by numbers) in Offshore station as a function of microcosm treatments. Green lines indicate significant $(p<0.05)$ positive correlations (Spearman) and red lines indicate significant $(\mathrm{p}<0.05)$ negative correlations. Solid lines indicate bacterial interactions with other OTUs and with phytoplankton groups, dotted lines indicate interactions between phytoplankton groups. Only 
1014 correlations $>|0.8|$ are indicated. C: Control, ACW: Artificial Contaminated Water and CW:

1015 Contaminated Water with sediment elutriate. See materials and methods for more details. 
CRediT author statement

Olivier PRINGAULT: Conceptualization, Methodology, Investigation, Writing - Original draft, Supervision; Marc BOUVY: Investigation, Ressources; Writing; Claire CARRE: Investigation; Ressources; Kaouther MEJRI: Investigation; Chrystelle BANCONMONTIGNY: Investigation; Catherine GONZALEZ: Investigation; Christophe LEBOULANGER: Validation; Asma SAKKA HLAILI: Project administration; Ressources; Marisol GONI-URRIZA: Writing; Investigation; Conceptualization 


\section{Declaration of interests}

$\bigotimes$ The authors declare that they have no known competing financial interests or personal relationships that could have appeared to influence the work reported in this paper.

$\square$ The authors declare the following financial interests/personal relationships which may be considered as potential competing interests:

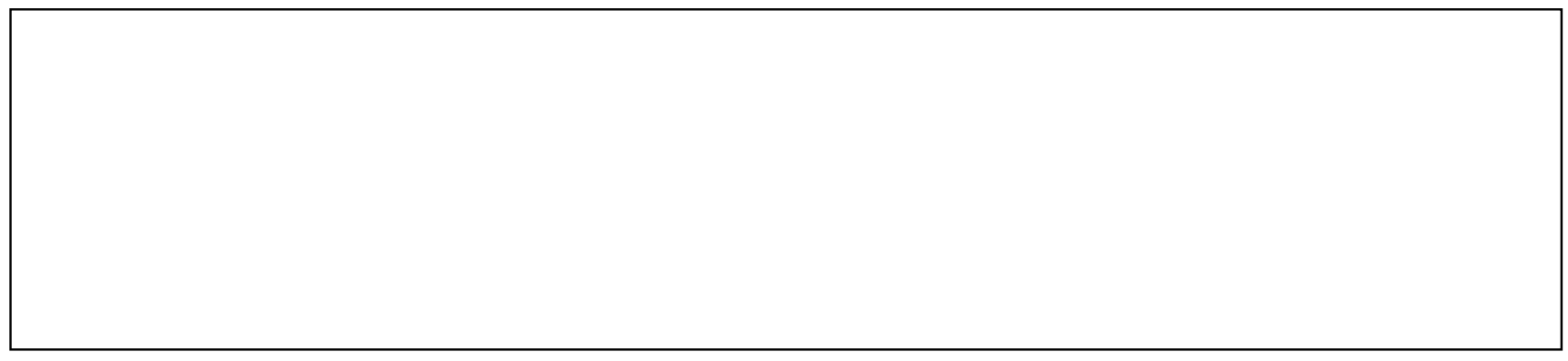



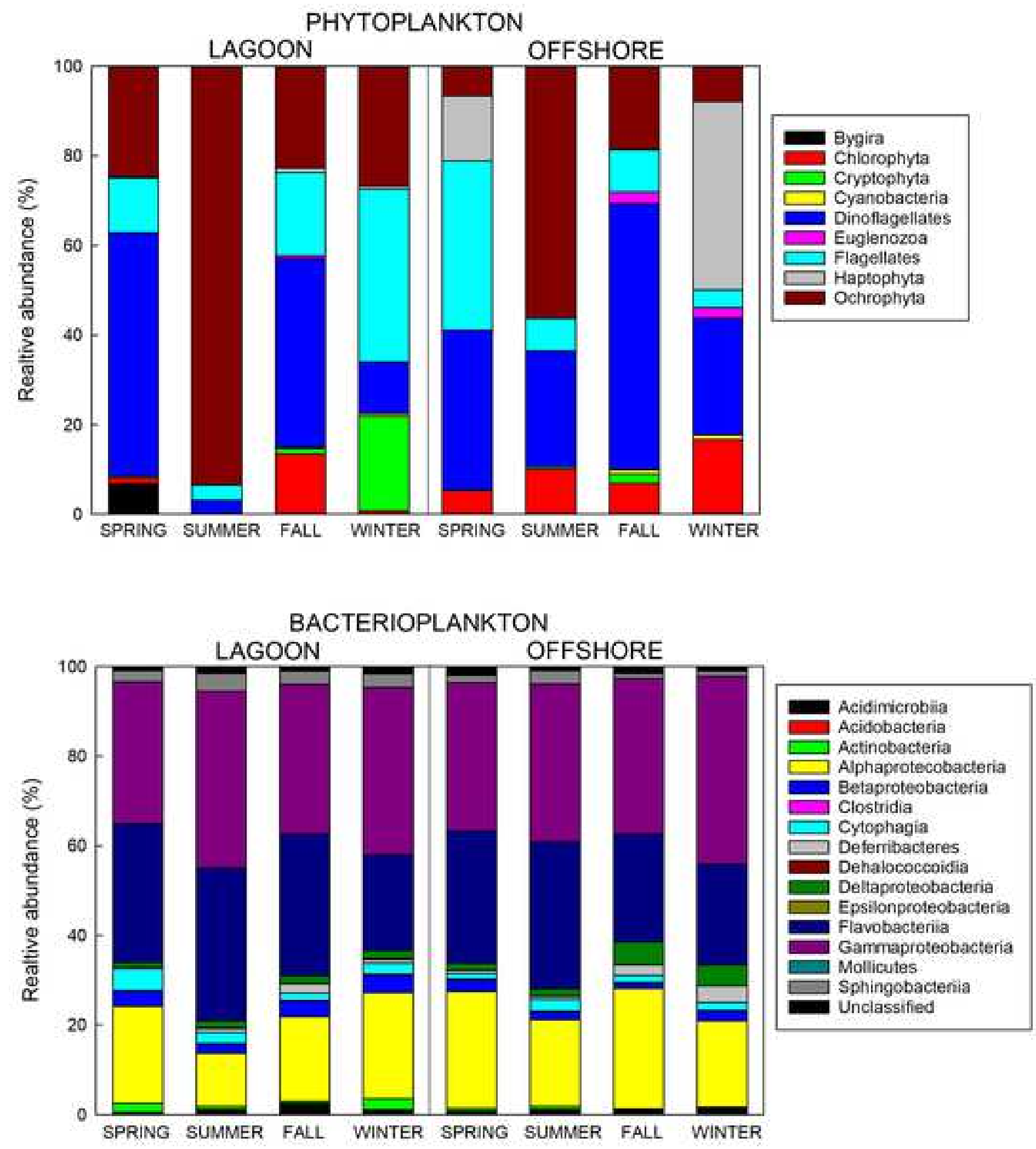

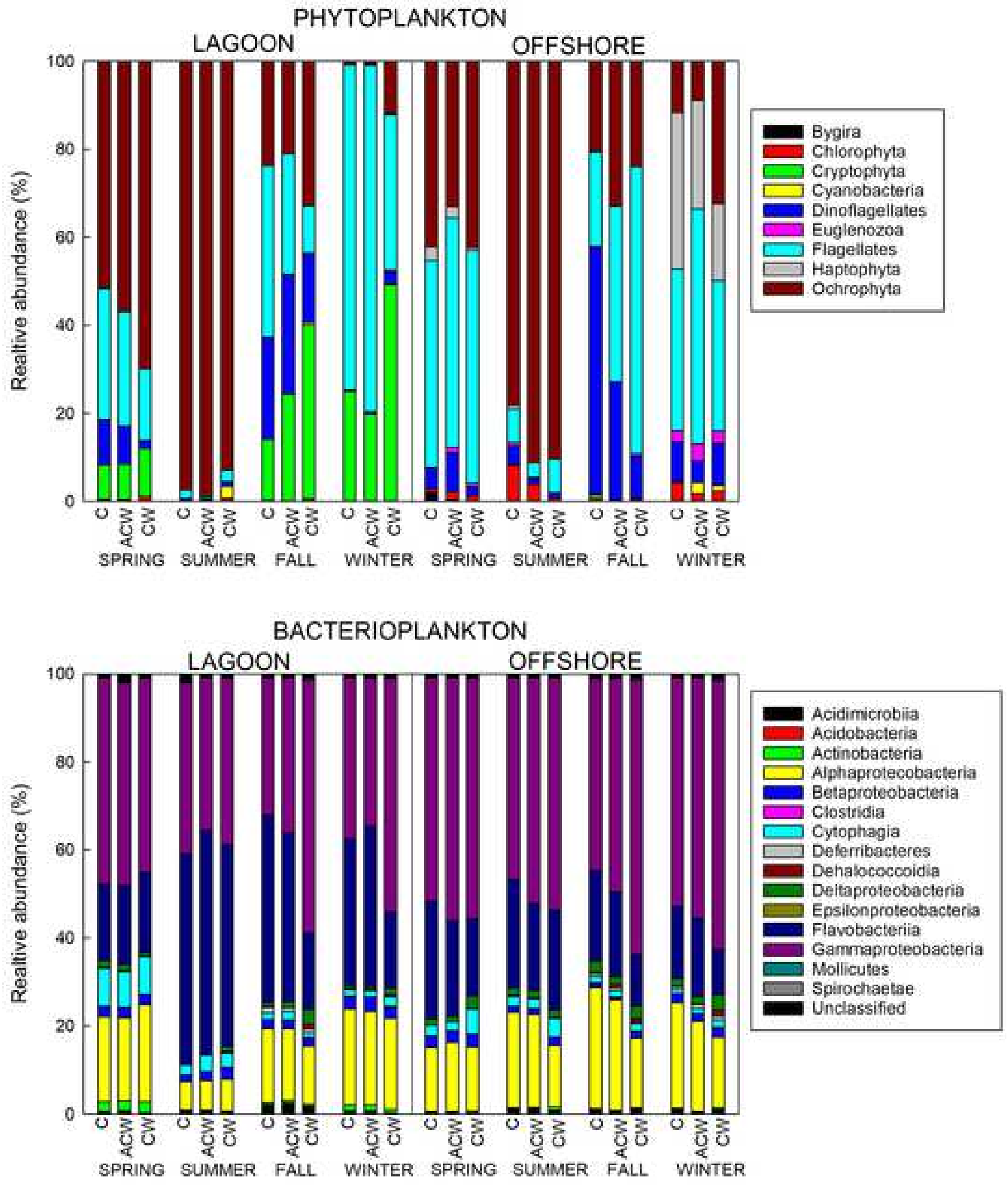


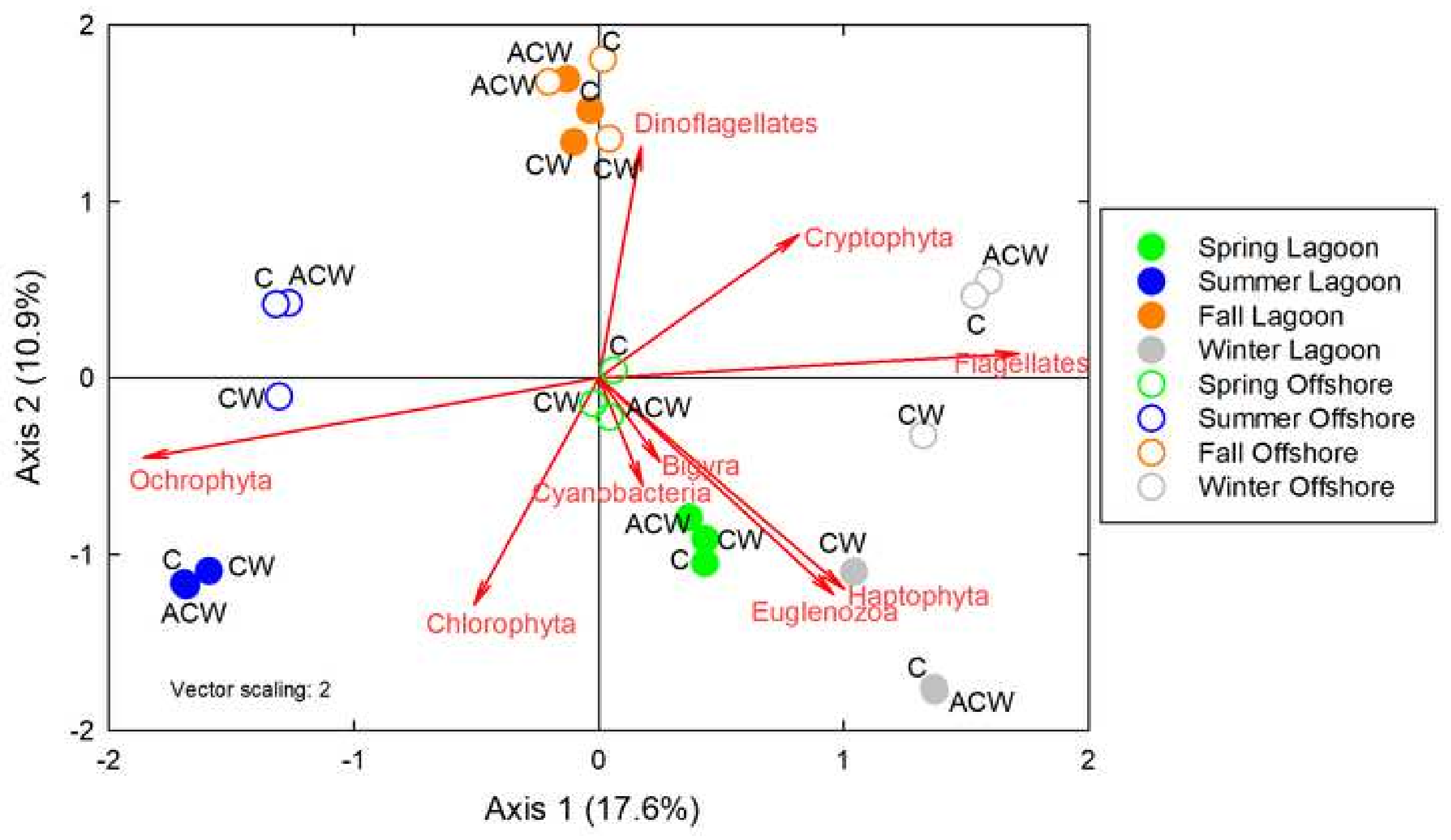


LAGOON

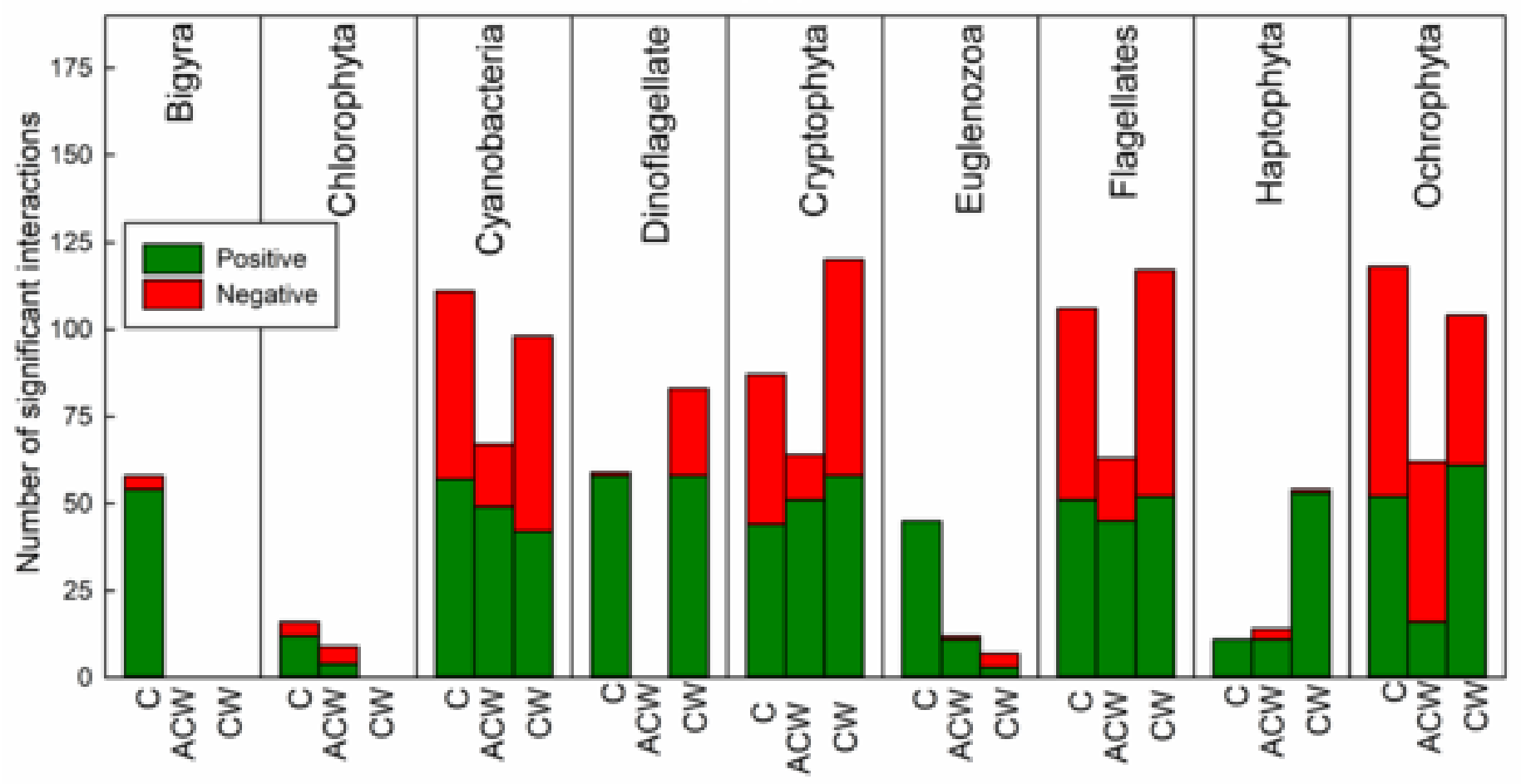

OFFSHORE

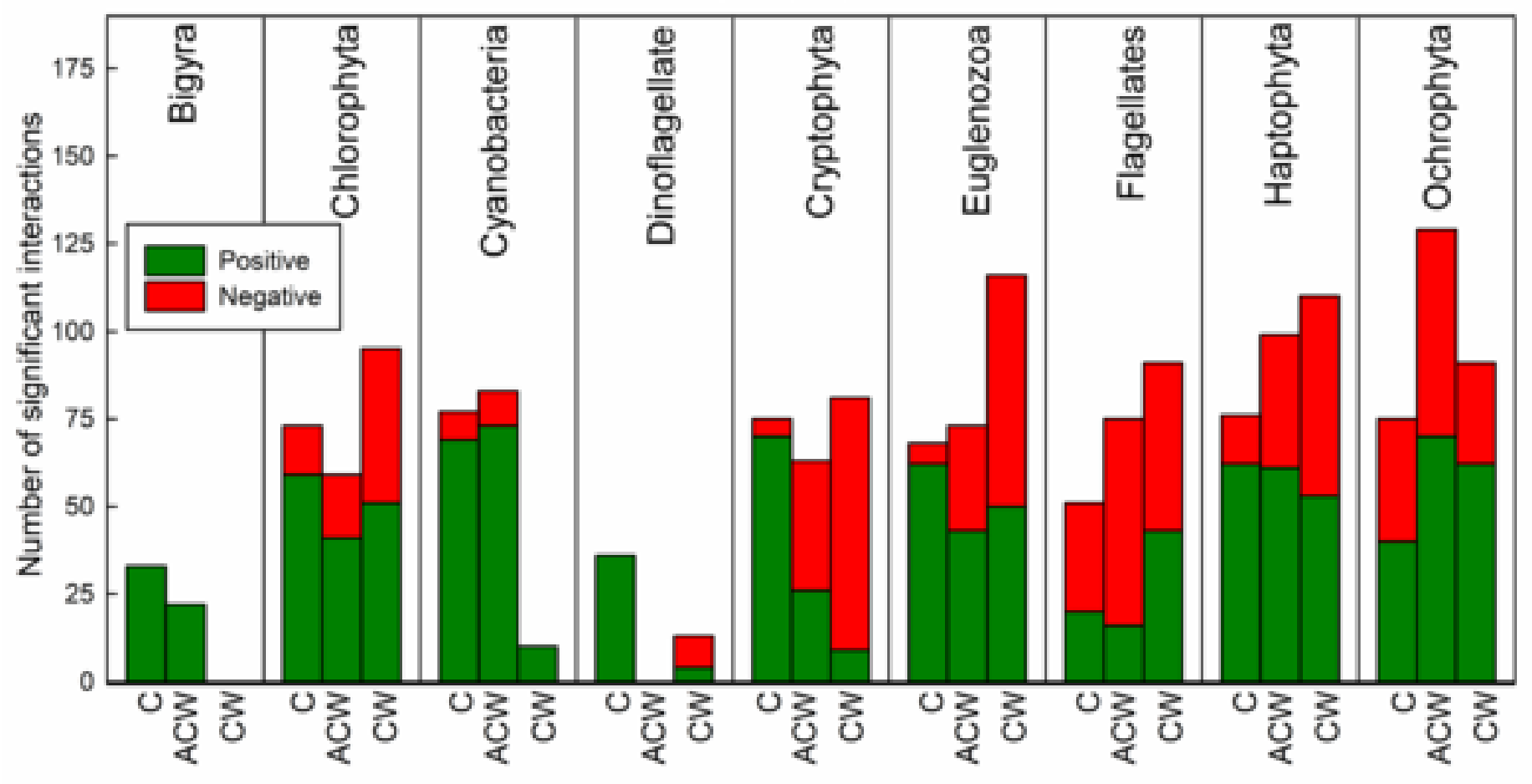




\section{LAGOON}

\section{CONTROL}
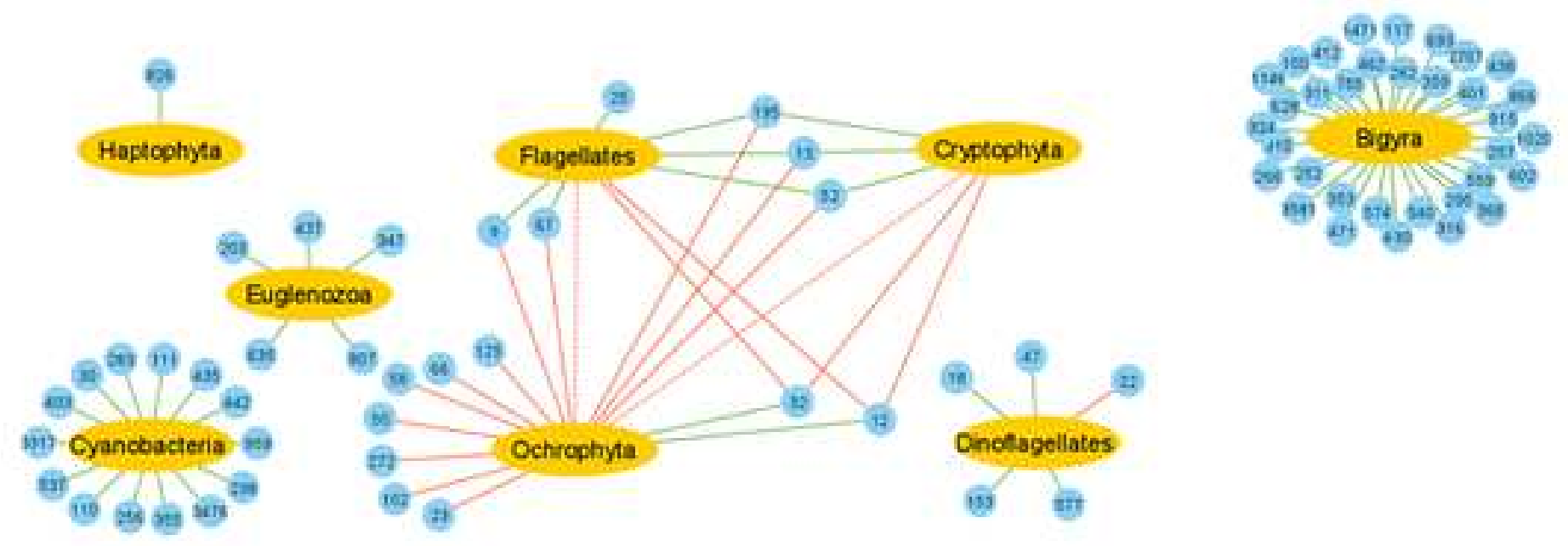

ACW

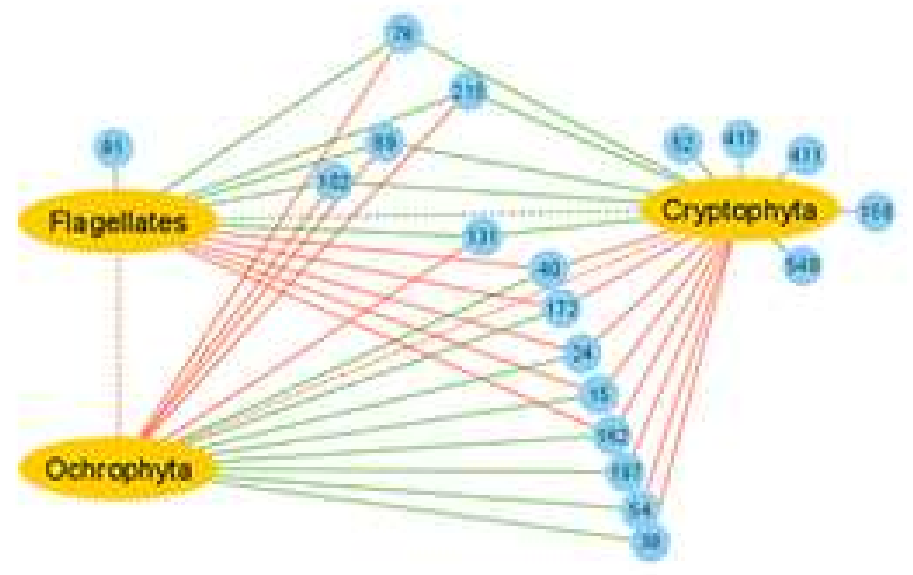

Chicrophyts

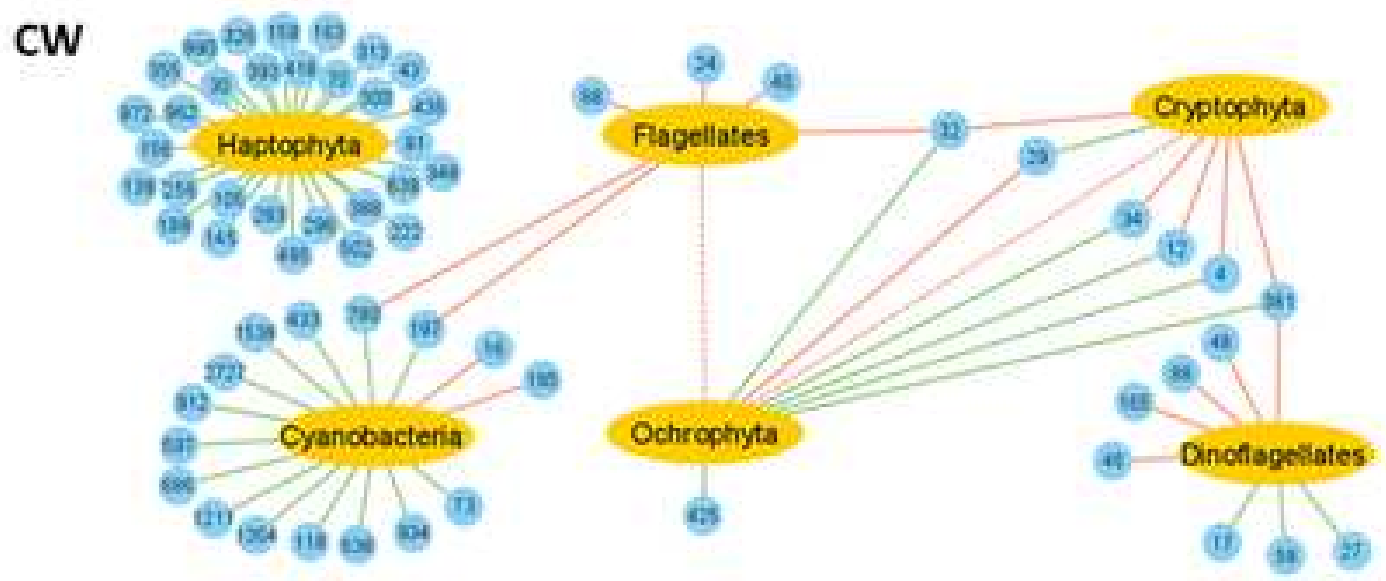




\section{OFFSHORE}

\section{CONTROL}

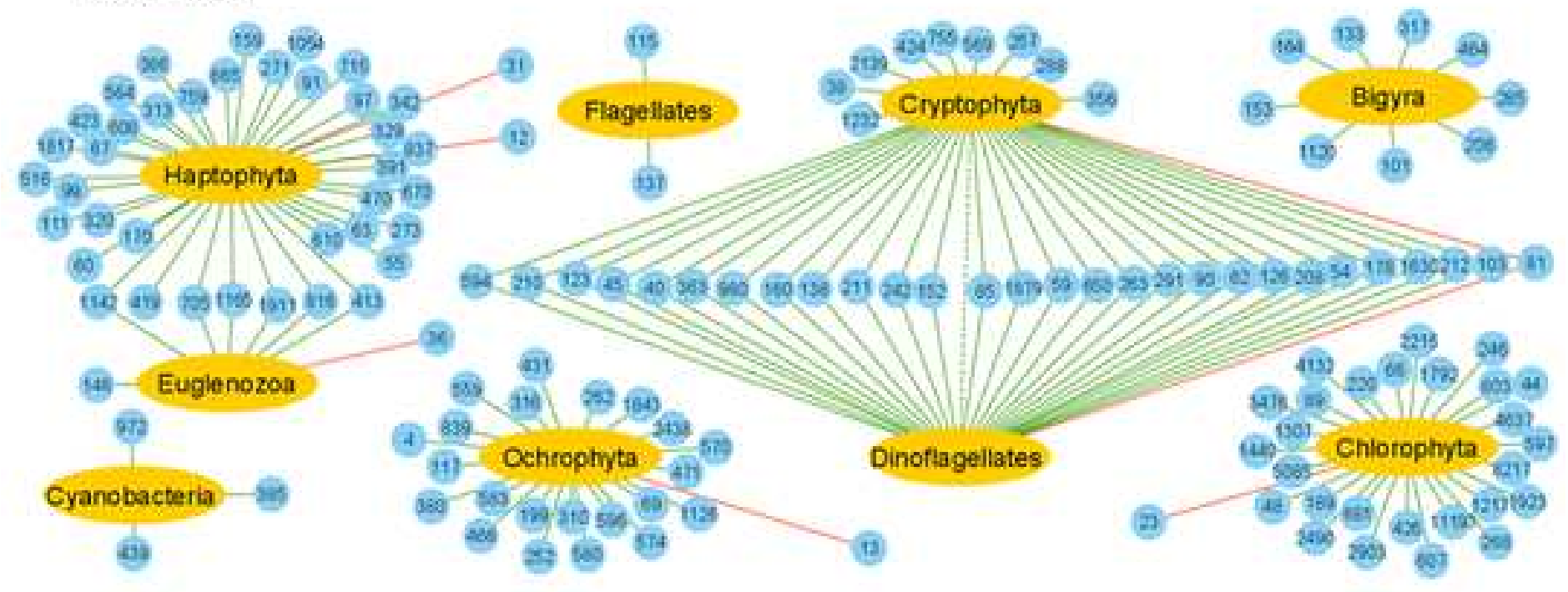

\section{ACW}
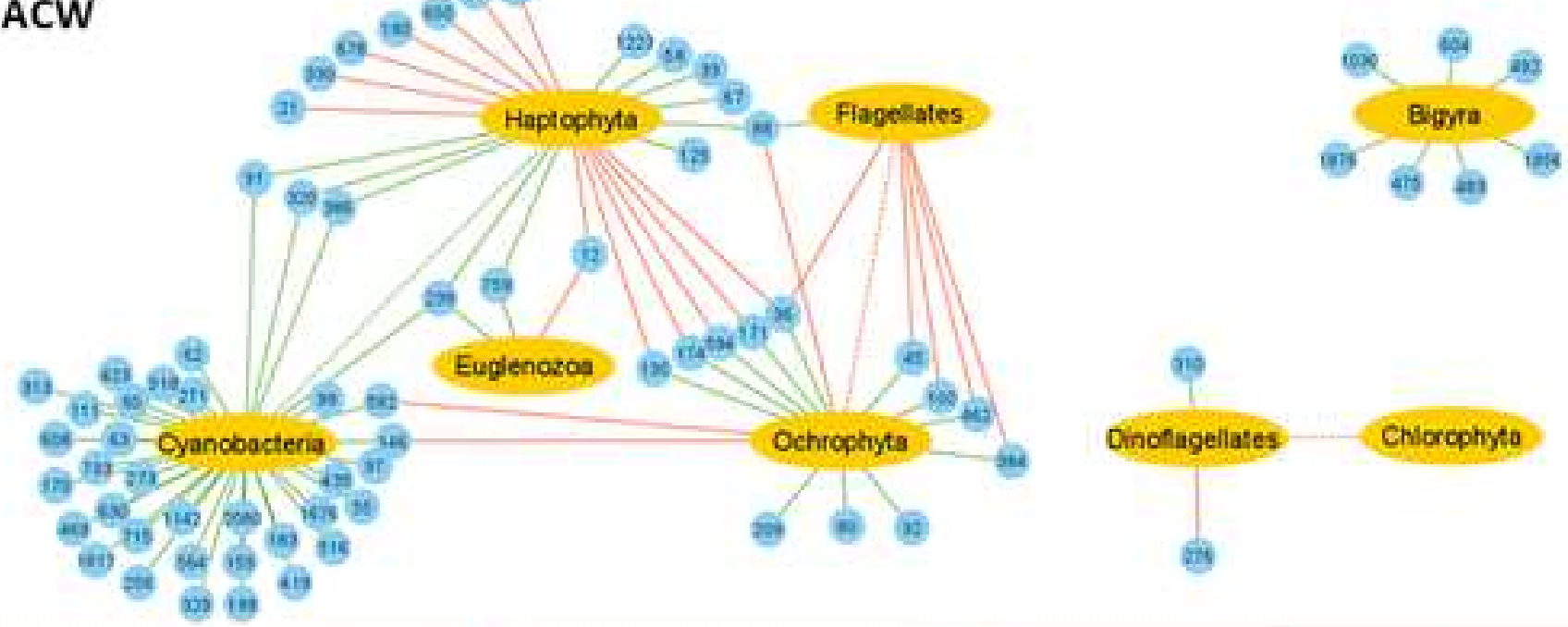

\section{CW}
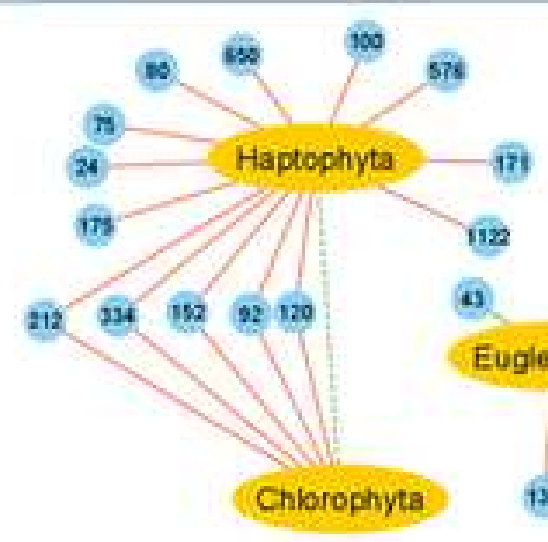

29

Flagellates - 12 210-Cryptophyta 293

(1)

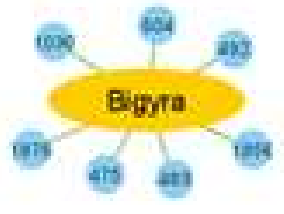

Eugienazoa

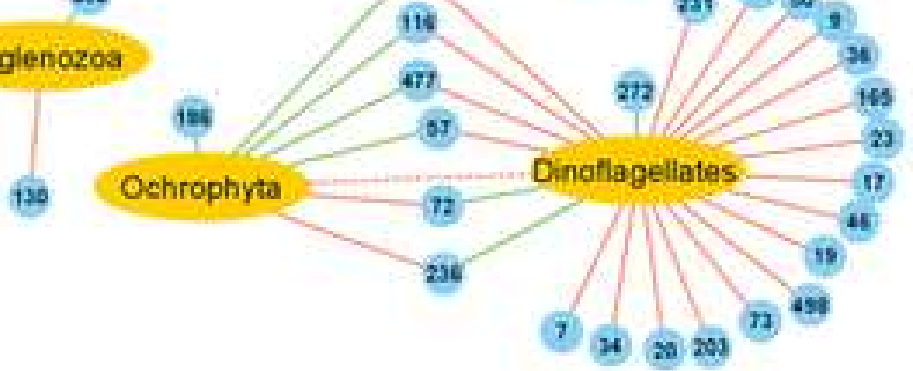


Click here to access/download Supplementary Material

Pringault et al Supplementary Materials Revised Version.docx 